\begin{tabular}{|c|c|}
\hline 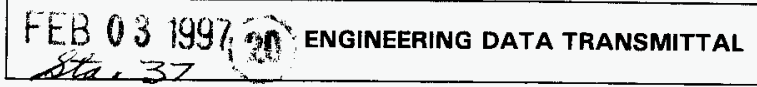 & 1. EDT 617442 \\
\hline
\end{tabular}

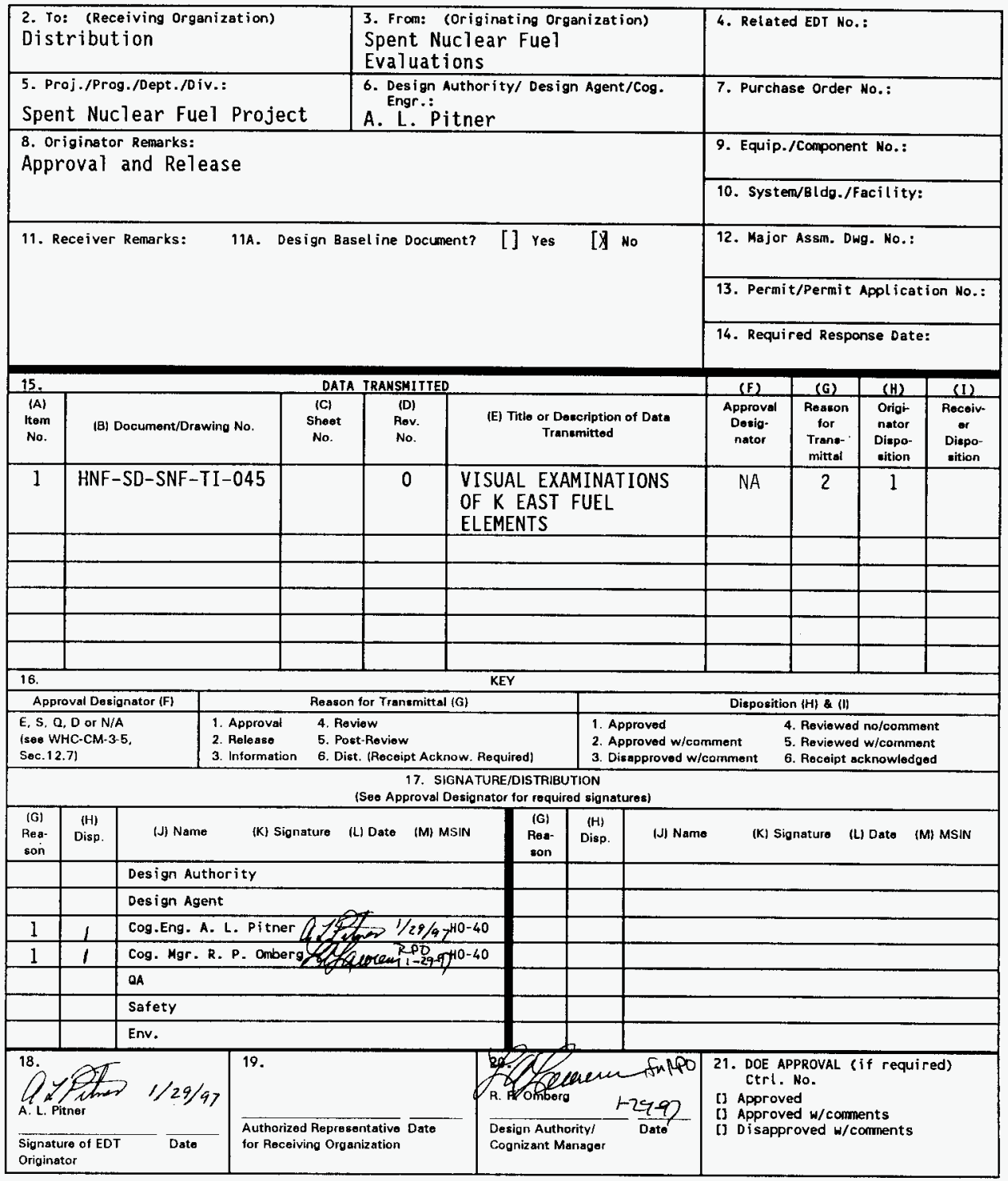

BD-7400-172-2(05/96) GEF097 


\section{VISUAL EXAMINATIONS OF K EAST FUEL ELEMENTS}

A. L. Pitner

Duke Engineering and Services Hanford, Inc., Richland, WA 99352

U.S. Department of Energy Contract DE-AC06-96RL13200

$\begin{array}{llll}\text { EDT/ECN: } & 617442 & \text { UC: } 2070 \\ \text { Org Code: } & 2 T 650 & \text { Charge Code: } & \text { LB024 } \\ \text { B\&R Code: } & \text { EW7070000 } & \text { Total Pages: } & 56\end{array}$

Key Words: K Basin, Fue1 Elements, Fuel Damage

Abstract: Selected fuel elements stored in both "good fuel" and "bad fuel" canisters in K East Basin were extracted and visually examined full length for damage. Lower end damage in the "bad fuel" canisters was found to be more severe than expected based on top end appearances. Lower end damage for the "good fuel" canisters, however, was less than expected based on top end observations. Since about half of the fuel in $K$ East Basin is contained in "good fuel" canisters based on top end assessments, the fraction of fuel projected to be intact with respect to IPS processing considerations remains at $50 \%$ based on these examination results.

TRADEMARK DISCLAIMER. Reference herein to any specific comercial product, process, or service by trade name, trademark, manufacturer, or otherwise, does not necessarily constitute or imply its endorsement, recomendation, or favoring by the United States Government or any agency thereof or its contractors or subcontractors.

Printed in the United States of America. To obtain copies of this document, contact: WHC/BCS Document Control Services, P.O. Box 1970, Mailstop H6-08, Richland WA 99352, Phone (509) 372-2420; Fax (509) 376-6989.
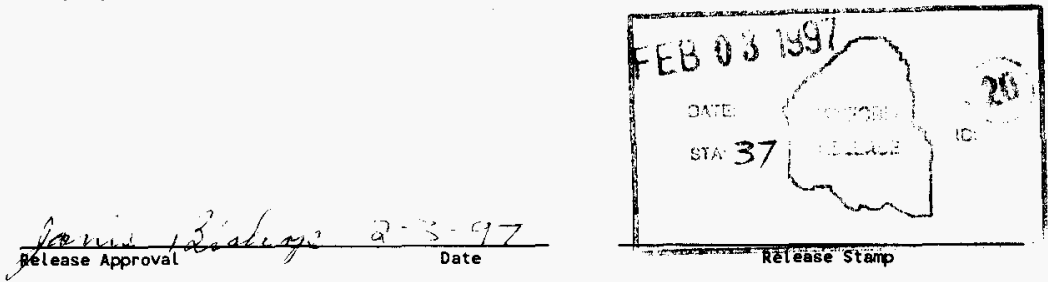

\section{Approved for Public Release}


HNF-SD-SNF-TI-045, Rev . 0

\section{CONTENTS}

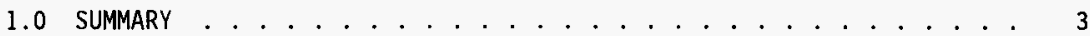

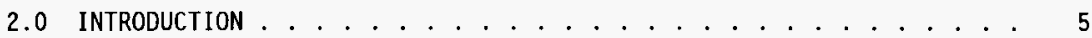

3.0 PROCEDURE . . . . . . . . . . . . . . . . . . 7

4.0 RESULTS . . . . . . . . . . . . . . . . . . . . 9

4.1 BAD FUEL SURVEY . . . . . . . . . . . . . . . 9

4.2 GOOD FUEL SURVEY .................. 10

4.3 EFFECT OF LOWER END CONDITIONS ON OVERALL FUEL RATING . . . . . 11

5.0 REFERENCES .......................... 13 
HNF-SD-SNF-TI-045, Rev. 0

\section{LIST OF FIGURES}

1. Intact Inner Element $(5569 \mathrm{~W}) \ldots \ldots . \ldots . \ldots 37$

2. Incipient Breach at Top of an Outer Element (6225E) . . . . . . 38

3. Inner Element with a Rupture at the Top (5554E) . . . . . . . 39

4. Outer Element with Detached Top End Cap (2350E) . . . . . . . . 40

5. Split Cladding at Top of Outer Element (2711E) . . . . . . . . 41

6. Crack Along the Side of an Outer Element (406W) . . . . . . . 42

7. Hole in Side of Outer Element Cladding (5069E) . . . . . . . . 43

8. Rust Blisters from Carbon Steel Shoe Corrosion (5565W) . . . . . 44

9. Blisters on Side of Outer Element where it Contacted Canister Wall (4156W) ............... 45

10. Outer Element Broken Near the Axial Midplane (5254E) . . . . . . . . 46

11. Sludge Ring Around the Bottom of an Outer Element (943E). . . . . . 47

12. Ruptured Bottom End of an Inner Element (2323W). . . . . . . . . 48

13. Outer Element with Loose End Cap and Split Cladding 49

14. Sludge Trail from the Open Bottom of an Outer Element (3128W) . . . 50

15. Canister Sludge Trail as Outer Element is Extracted (6225E) . . . . 51

16. Defected Top End of an Outer Element (5554E) . . . . . . . . 52

17. Good Bottom End of Element in Figure 16 (5554E) . . . . . . . 53

18. Category Changes for the Good Fuel Survey . . . . . . . . . . 54

19. Category Changes for the Bad Fuel Survey . . . . . . . . . . . . 55

\section{LIST OF TABLES}

1. Bad Fuel Survey Results . . . . . . . . . . . . . . . 15

2. Good Fuel Survey Results ... . . . . . . . . . . . . 19

3. Comparison of Top End and Lower End Fuel Conditions . . . . . . 35 
HNF-SD-SNF-TI-045, Rev. 0

\section{VISUAL EXAMINATIONS OF $K$ EAST FUEL ELEMENTS}

\subsection{SUMMARY}

When fuel samples for laboratory evaluation were taken from nine $K$ East Basin canisters containing known damaged fuel, the general condition of the fuel in these "bad fuel" canisters was found to be more degraded on the lower ends than expected based on top end conditions. This raised concern about the actual lower end conditions of $50 \%$ of the fuel in the basin thought to be intact based on top end appearances. Accordingly, a second fuel examination campaign was conducted on "good fuel" canisters where full length visual inspections were performed on extracted elements.

The "bad fuel" examinations were fairly limited (about 25 assemblies). Although there was substantial top end damage apparent in these fuel assemblies, lower end damage such as split cladding or element breakage was greater than expected based on top end damage observations. Nearly $60 \%$ of the

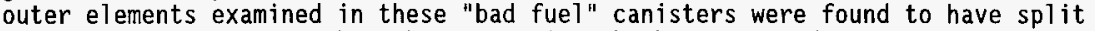
cladding on one end or the other (sometimes both), compared to an estimated $5 \%$ split cladding frequency for the overall fuel population in the basin based on top end visual surveys.

The "good fuel" examinations were more extensive (about 200 assemblies). Some of the fuel elements in these inspections showed minor damage on the top ends such as a cladding breach with a small amount of reacted fuel present, but no gross damage such as split or dilated cladding. While some additional lower end defects were found in the examinations, they were at only about half the frequency expected based on top end defect occurrences. Major damage such as split cladding or element breakage was found on only about $3 \%$ of the elements examined in these "good fuel" canisters.

It appears that the degree of lower end degradation found in $K$ East Basin fuel is dependent on the general condition of the fuel in the canisters. For canisters that contain fuel in relatively good condition based on top end observations, little additional degradation is found at lower levels. For canisters that contain conspicuously degraded fuel on the top ends, however, substantial further degradation of the fuel at lower levels is common. Since about half of the fuel in K East Basin is contained in "good fuel" canisters based on top end assessments, the fraction of fuel elements projected to be intact with respect to IPS processing considerations remains at $50 \%$. 
HNF-SD-SNF-TI-045, Rev. 0

This page intentionally left blank. 


\subsection{INTRODUCTION}

A comprehensive survey of all visible fuel in the $K$ East Basin was conducted in the summer of 1994 (Pitner 1995). In that survey, no fuel handling was performed and the viewing was basically limited to the top ends of the fuel assemblies. Based on the observed top end conditions and assuming the same defect frequencies on the bottom ends, it was estimated that about half of the fuel assemblies in the basin were intact and in relatively good condition, but about $4 \%$ of the assemblies were in a state of gross deterioration (Pitner 1996). The remainder of the fuel was rated to be in intermediate categories.

In the spring of 1996, a campaign was conducted in the $\mathrm{K}$ East Basin to extract fuel elements from nine different canisters and ship them to a hot cell for detailed examination. The objective was to obtain fuel elements that were highly degraded so that handling and processing requirements for this type of fuel for MCO storage could be defined (Lawrence 1996). During the fuel sampling process, full length visual examinations were performed on a number of fuel elements from each of the candidate canisters. While the fuel elements examined in this campaign were known to be in poor condition, the observed degree of degradation was generally more severe than suggested from top end appearances. A significant fraction of the fuel elements examined were found to be broken into two or more pieces at some lower level, and fuel sludge often trailed from breach openings when the fuel was handled.

The observed degree of degradation of this "bad" fuel raised concern about the remaining fuel in the basin. In particular, it was questioned whether the $50 \%$ fraction of fue 7 thought to be in good condition was in fact still intact at lower levels. Accordingly, a second examination campaign was planned and conducted that concentrated on canisters that contained "good" fuel. These canisters sometimes contained fuel with moderate defects (breached cladding with some reacted fuel visible), but no badly degraded elements with split or dilated cladding based on top end appearance. Some thirty canister barrels containing 210 fuel assemblies were involved in this second campaign. The candidate canisters were selected to be representative of basin location and canister type (stainless steel or aluminum). Since most of the good fuel in the basin is loaded in stainless steel canisters, the relative number of canisters selected was weighted in this direction.

This report details the observations made in these two visual fuel surveys. 
HNF-SD-SNF-TI-045, Rev. 0

This page intentionally left blank. 


\subsection{PROCEDURE}

The examination procedure typically was to move the candidate canister to the inspection location, extract an inner element and examine it full length while videotaping, extract the corresponding outer element and examine it while the inner element was positioned aside, and then replace the elements back in their original locations in the canister. For the "bad" fuel survey, the fuel assembly selected for hot cell examination was inspected along with two other fuel assemblies in the same canister barrel. For the "good" fuel survey, all seven assemblies in the candidate canister barrels were typically examined. After the visual inspections were completed for each canister, the canister was returned to its basin location and the next candidate canister was moved to the examination station.

Each element was examined for the following conditions. For the top end, each element was placed in at least one of the five categories described (on a few occasions the element had both a loose end cap and split cladding). For the sides and bottom ends, features were noted as appropriate.

\section{Top End}

Intact -

Incip. Breach -

Rupture -

Loose End Cap -

Split Cladding -
No evidence of cladding failure. Figure 1 shows an intact inner element that still has the spacer clips and $W$ springs attached. The number in parentheses in the figure caption indicates the location of the canister barrel in which the element resided.

An indication of possible loss of cladding integrity, but with no reacted fuel evident. Figure 2 shows an example of incipient breach on the top end of an outer element.

A definite breach in the cladding with reacted fuel generally visible. A ruptured inner element is shown in Figure 3.

The end cap is separated from the Zircaloy cladding. The end cap in missing from the top end of the outer element shown in Figure 4.

The cladding is peeled open, presumably from the volume expansion associated with the uranium-water reaction. Figure 5 shows an outer element with split cladding at the top end. The outer element to right and below the extracted element being examined also has a split cladding condition.

\section{Side}

Cracks -
Visible cracks along the side of the element, presumably from swollen reacted fuel, as shown in Figure 6 . 
Hole -

B1isters -

Broken -

A small hole in the side of the element. An example is shown in Figure 7.

Either rust blisters from corrosion of the carbon steel shoes on the spacer clips, or blisters along the side of the element where it contacted the canister, possibly from galvanic reaction. These were seen on fuel elements contained in both stainless steel and aluminum canisters. Figure 8 shows an example of a rusted shoe. There is also a rust blister at the top of the element where it contacted the rusty shoe of an adjacent element. Figure 9 shows blisters along the side of an outer element where it contacted the canister wall. Neither of these blister types are believed to be particularly damaging; they are easily removed by moderate physical contact.

The element is broken into two (or more) parts at some lower axial level. Figure 10 shows an outer element broken near the axial midplane. No incidences of broken inner elements were observed in these surveys. Sludge was frequently seen to pour from the ends of broken outer fuel elements. No attempts were made to extract the lower section(s) of broken elements.

\section{Bottom End}

Sludge Ring Hgt - The estimated height of the dark band often seen around the bottom of fue 1 elements, presumably a consequence of being buried in canister sludge. Figure 11 shows a band about 1 inch high around the bottom of an outer element.

Rupture -

A definite indication of cladding breach on the lower end. Figure 12 shows ruptured cladding on the bottom end of an inner element.

Loose End Cap - The end cap on the bottom end is detached. The end cap is missing from the bottom end of the outer element shown in Figure 13. The clarity is diminished in the photo because of sludge released from the open bottom end.

Split Cladding - The cladding on the lower end is split open. The element shown in Figure 13 with the missing end cap also has split cladding at the bottom end. 
HNF-SD-SNF-TI-045, Rev. 0

\subsection{RESULTS}

\subsection{BAD FUEL SURVEY}

The results of this fuel condition assessment are presented in Table 1. Fuel elements from nine canister barrels were examined in this survey. The " $E$ " or " $W$ " designation on the Canister identification indicates whether the east or west barrel of the canister as it is stored in the basin was examined. The type of canister (stainless steel or aluminum) is also indicated for each sampling. The incidences of the above defect observations are recorded for each canister examined. At the end of the table is a summary tabulation of the observations. In all, 24 inner elements and 26 outer elements contained in these "damaged fuel" canisters were visually evaluated to some degree.

The sludge ring around the bottom of both the inner and outer elements was generally 1 to 2 inches high, although a few greater and lesser values were observed. One inner element had a sludge ring at least 12 inches high. This inner element resided in an outer element broken at an axial level that appeared to correspond to the sludge ring height. Where sludge ring heights are not reported, the elements are broken at some mid-axial level and the bottom sludge rings could not be viewed.

The degradation level in these "damaged fue $1 "$ canisters is exemplified by the frequency of split cladding observed. Nearly $60 \%$ of the outer elements examined here had split cladding. In two cases, the cladding was split on both ends of the element. The $60 \%$ frequency of split cladding in these canisters is in dramatic comparison to a $5 \%$ frequency (including bottom end estimates) for the overall basin visual survey previously conducted (Pitner 1995).

It is of interest to compare the relative frequency of bottom end defects to those observed on the top end. For the inner elements examined, 3 of the 24 (13\%) elements were found to be ruptured on the top end. Applying the same $13 \%$ frequency to the remaining 21 apparently intact elements (includes incipient breaches based on top end viewing), 3 additional elements would be expected to be found ruptured on the lower end (includes sides and bottom). In fact, 3 additional breaches were found. For the outer elements, 17 of the $26(65 \%)$ examined had top end ruptures. Applying this $65 \%$ frequency to the remaining 9 e? ements with good top ends (intact plus incipient breaches), 6 additional lower end defects would be expected to be found. In actuality, 8 of the 9 elements with good top ends were defected on their lower ends.

The high degree of degradation of the fuel in these canisters is further exemplified by the number of outer fuel elements found to be broken when extracted from the canisters. Nearly one-third of all the outer elements examined were broken at some lower axial level, with sludge generally observed to pour form the broken end when the element was handled. Figure 14 shows sludge trailing from the bottom open end of an outer fuel element as it is being transferred to a shipping container for hot cell examination. This type of sludge was quite heavy and settled rather quickly, as compared to floor type sludge which is much more flocculent and remains suspended in the water longer when disturbed. 
HNF-SD-SNF-TI-045, Rev. 0

\subsection{GOOD FUEL SURVEY}

While the attempt was made to examine all 210 assemblies in the 30 candidate canister barrels, occasional grappling difficulties precluded the inspection of a number of elements. In al1, 201 inner elements and 199 outer elements were extracted and visually examined. Results of these examinations are presented in Table 2. The results are given for each canister barrel examined in order of ascending canister number. Within each canister listing, the position of the elements advances clockwise with element number, with No. 1 being in the east most location in its basin storage cubicle. The No. 7 elements are loaded in the center of the canister. Where there is no information given for a particular element, it indicates that the element could not be grappled for extraction and examination. The type of canister (stainless steel or aluminum) is also identified in Table 2. Only four of the thirty canisters examined were aluminum, reflecting the relative population of good fuel in these types of canisters. At the end of the table is a summary tabulation of the observations.

Although more than half of the elements (mostly outers) left significant sludge trails when extracted from the canisters, there appeared to be no correlation with lower end damage. Figure 15 shows a typical sludge trail behind an outer element being extracted. This sludge was generally quite flocculent and was believed to be floor type sludge lying in the bottom of the canister. Previous observations of fuel sludge trailing from the open bottom of bad fuel elements demonstrated that this type of sludge settles much faster than the sludge observed in the current examinations. Fuel elements examined here however did generally display dark bands around the bottom ends, apparently from being buried in the canister sludge. Sludge bands as high as 2 inches were occasionally observed, but generally they were on the order of $1 / 2$ inch or less. About a quarter of the elements examined had no detectable sludge band at all.

of the 201 inner elements examined, 17 were noted to have significant top end defects (ruptured cladding or loose end cap). For the 199 outer elements examined, 41 had significant top end defects. Although a number of lower end defects were found in the examinations, there was no evidence that elements with top end defects influenced the condition of adjacent fuel elements; i.e., no indication of a damaged element causing degradation of neighboring elements. The elements that did have significant top end defects were generally found to be intact at lower levels. Further lower end defects on elements with top end defects were found on only 1 inner element and 2 outer elements. Figure 16 shows the defected top end of an outer element, and Figure 17 shows the bottom end of the same element. Although rust blisters are present on the bottom end, there is no indication of loss of integrity.

Considering the number of lower end defects found relative to what might be expected based on top end defect frequencies, considerably less damage was identified on the lower ends. For the inner elements, there were 184 elements that appeared intact on the top ends (includes incipient breaches). Incipient breaches on the bottom ends would be very difficult to identify, inasmuch as direct end on viewing was not available. Conspicuous ruptures were visible on the top end of 17 of the 201 inner elements examined (8\%). Applying this same $8 \%$ fraction to the 184 elements with good top ends, about 16 bottom end 
defects would be expected to be found. In actuality, only 8 defects were identified, for a $4 \%$ defect frequency. For the outer elements, 41 ruptures were noted on the top ends of the 199 elements examined (21\%). Applying this $21 \%$ fraction to the 158 elements with good top ends, about 33 lower end ruptures would be anticipated. Only 18 lower end defects were actualiy found, for an $11 \%$ defect frequency. Again, these discrepancies may in part be due to the poorer viewing conditions on the bottom ends; i.e., no end on viewing, making small ruptures difficult to identify.

\subsection{EFFECT OF LOWER END CONDITIONS ON OVERALL FUEL RATING}

As would be expected, observations of lower end degradation can reduce the overall integrity rating of fuel elements. Elements intact on the top end would change to a worse category if lower end damage were found. For elements defected on the top end, good physical integrity on the lower end would not improve their overall rating, but more severe lower end damage would cause a change to a worse category. Thus, it is to be expected that overall ratings should decrease when lower end damage observations are incorporated.

To make the assessment of increased degradation from lower end damage more manageable, the rating categories for fuel condition are consolidated somewhat according to the following definitions:
Intact -
Intact or Incipient Breach
Ruptured -
Definite cladding breach with reacted fuel evident, cracks in the side of the cladding, or a hole in the side of the cladding
Bad -
An element with an open end (detached end cap), split cladding, or a break at some intermediate axial level.

Comparisons of top end and lower end fuel conditions for the two surveys are given in Table 3 . For the Good Fuel Survey, relatively few inner and outer elements that were intact on their top end showed lower end damage that would change their rating to a worse category. The elements that did show top end damage in this survey were for the most part intact on the lower end. In al1, only $4 \%$ of the inner elements and $10 \%$ of the outer elements in the Good Fuel Survey changed to a worse category based on lower end conditions.

For the Bad Fuel Survey, few changes in rating based on lower end observations were noted for the inner elements. For the outer elements, however, changes to worse categories were common. Eight of nine elements with intact top ends changed to the "Ruptured" or "Bad" categories. The two outer elements with top end ruptures changed to the "Bad" category, and about half of the elements with bad top ends had defected (Ruptured or Bad) lower ends as we11. In a11, 13\% of the inner elements and 38\% of the outer elements in the Bad Fuel Survey changed to a worse category based on lower end conditions.

The category changes for these two fuel surveys are illustrated graphically in Figures 18 and 19 . In the figures, the relative distributions within the three specified categories are presented for initial top end and 
for the overall (incorporates lower end observations) ratings. For the Good Fuel Survey (Figure 18), the changes in rating are moderate, particularly for the inner elements. For the Bad Fuel Survey (Figure 19), the changes to worse categories are quite dramatic, particularly for the outer elements.

It appears that the degree of lower end degradation found in the $K$ East Basin fuel is dependent on the general condition of the fuel in the canisters. For canisters that contain fuel in relatively good condition based on top end observations, little additional degradation is found at lower levels. For canisters that contain conspicuously degraded fuel on the top ends, however, further substantial degradation of the fuel at lower levels is common. Since about half the fuel in the $K$ East Basin is judged to be in canjsters rated as "Good" (Pitner 1995), the 50\% fraction of the fuel assemblies rated to be "Intact" (Pitner 1996) is expected to remain so with respect to IPS processing considerations. 
HNF-SD-SNF-TI-045, Rev. 0

\subsection{REFERENCES}

Lawrence, L. A., 1996, Data Quality Objectives for the $K$ East Fue Examinations, WHC-SD-SNF-DQ0-009, Rev. 0, February 1996.

Pitner, A. L., 1995, K East Basin Underwater Visual Fuel Survey, WHC-SD-SNF-TI-012, Rev. 0, February 1995.

Pitner, A. L., 1996, K East Fuel Cleanliness Evaluation, WHC-SD-SNF-TI-018, Rev. 0, January 1996. 
HNF-SD-SNF-TI-045, Rev. 0

This page intentionally left blank. 
HNF-SD-SNF-TI-045, Rev. 0

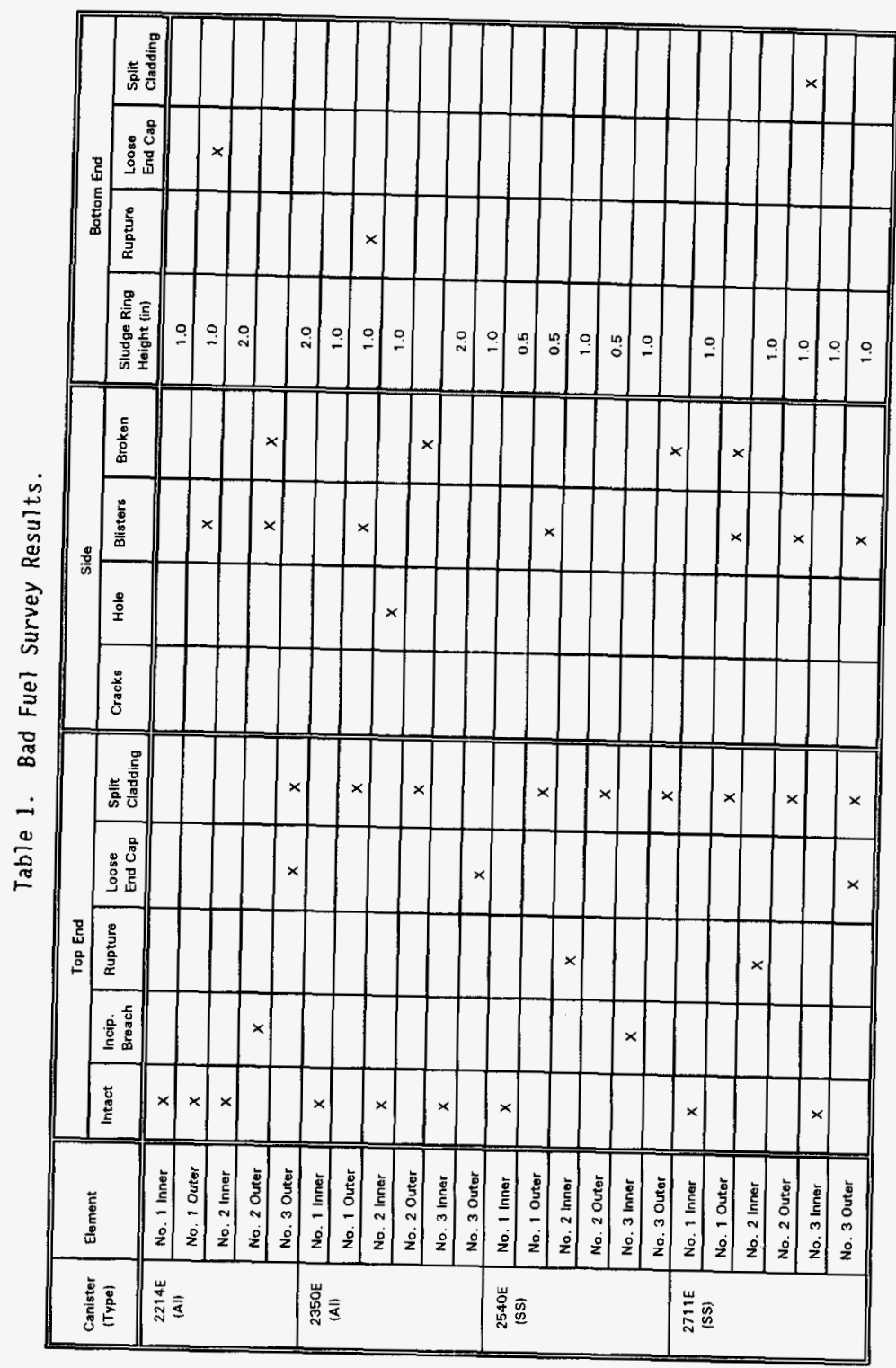


Table 1. Bad Fuel Survey Results. (Continued)

\begin{tabular}{|c|c|c|c|c|c|c|c|c|c|c|c|c|c|c|}
\hline \multirow[b]{2}{*}{$\begin{array}{l}\text { Canister } \\
\text { (Type) }\end{array}$} & \multirow[b]{2}{*}{ Element } & \multicolumn{5}{|c|}{ Top End } & \multicolumn{4}{|c|}{ Side } & \multicolumn{4}{|c|}{ Bottom End } \\
\hline & & Intact & $\begin{array}{l}\text { Incip. } \\
\text { Breach }\end{array}$ & Rupture & $\begin{array}{l}\text { Loose } \\
\text { End Cap }\end{array}$ & $\begin{array}{l}\text { Split } \\
\text { Cladding }\end{array}$ & Cracks & Hole & Blisters & Broken & $\begin{array}{l}\text { Sludge Ring } \\
\text { Height (lin) }\end{array}$ & Rupture & $\begin{array}{l}\text { Loose } \\
\text { End Cap }\end{array}$ & $\begin{array}{l}\text { Split } \\
\text { Cladding }\end{array}$ \\
\hline \multirow{6}{*}{$\begin{array}{l}2722 E \\
\text { (SS) }\end{array}$} & No. 1 Inner & $x$ & & & & & & & & & 1.0 & & & \\
\hline & No, 1 Outer & & & & & $x$ & & & & & & & & \\
\hline & No. 2 Inner & $x$ & & & & & & & $x$ & & 1.0 & & & \\
\hline & No. 2 Outer & & & & $\mathrm{x}$ & $x$ & & & & & 2.0 & $x$ & & \\
\hline & No. 3 Inner & $x$ & & & & & & & & & 1.0 & & & \\
\hline & No. 3 Outer & & $x$ & & & & & & $x$ & & 1.0 & & & \\
\hline \multirow{4}{*}{$\begin{array}{l}3128 \mathrm{~W} \\
\text { (SS) }\end{array}$} & No. 1 Inner & $\mathrm{x}$ & & & & & & & $x$ & & 1.0 & & & \\
\hline & No. 1 Outer & $x$ & & & & & $x$ & & $x$ & $x$ & & & & \\
\hline & No. 2 Inner & $x$ & & & & & & & & & 3.0 & & & \\
\hline & No. 2 Outer & $x$ & & & & & & $x$ & $x$ & & 3.0 & & $x$ & \\
\hline \multirow{6}{*}{$\begin{array}{c}5069 \mathrm{E} \\
|\mathrm{A}| \mid\end{array}$} & No. 1 Inner & & $x$ & & & & & & & & 1.0 & & & \\
\hline & No. 1 Outer & & & $x$ & & & & $x$ & $x$ & & 1.0 & & $x$ & $x$ \\
\hline & No. 2 Inner & $x$ & & & & & & & & & 1.0 & & & \\
\hline & No. 2 Outer & & & $x$ & & & & & & & 1.0 & & $x$ & $x$ \\
\hline & No. 3 inner & $\mathrm{x}$ & & & & & & & & & 3.0 & & & \\
\hline & No. 3 Outer & & & & $x$ & & & & & & & & & \\
\hline \multirow{5}{*}{$\begin{array}{l}5427 E \\
\text { (Af) }\end{array}$} & No. 1 Inner & $x$ & & & & & $x$ & & & & 0.5 & & & \\
\hline & No. 1 Outer & & $x$ & & & & & & & $x$ & & & & \\
\hline & No. 2 Inner & $x$ & & & & & & & & & 1.0 & & & \\
\hline & No. 2 Outer & & $x$ & & & & & & & $x$ & & & & \\
\hline & No. 3 Outer & & & & $x$ & $\mathrm{x}$ & $x$ & & & & 1.0 & & & $x$ \\
\hline
\end{tabular}


Table 1. Bad Fuel Survey Results. (Continued)

\begin{tabular}{|c|c|c|c|c|c|c|c|c|c|c|c|c|c|c|}
\hline \multirow{2}{*}{$\begin{array}{l}\text { Canister } \\
\text { (Type) }\end{array}$} & \multirow{2}{*}{ Element } & \multicolumn{5}{|c|}{ Top End } & \multicolumn{4}{|c|}{ Side } & \multicolumn{4}{|c|}{ Bottom End } \\
\hline & & Intact & $\begin{array}{l}\text { Incip. } \\
\text { Breach }\end{array}$ & Rupture & $\begin{array}{l}\text { Loose } \\
\text { End Cap }\end{array}$ & $\begin{array}{l}\text { Split } \\
\text { Cladding }\end{array}$ & Cracks & Hole & Blisters & Broken & $\begin{array}{l}\text { Sludge Ring } \\
\text { Height (in) }\end{array}$ & Rupture & $\begin{array}{l}\text { Loose } \\
\text { End Cap }\end{array}$ & $\begin{array}{l}\text { Split } \\
\text { Cladding }\end{array}$ \\
\hline \multirow{6}{*}{$\begin{array}{c}\text { 5608E } \\
\text { (SS) }\end{array}$} & No. 1 Inner & $x$ & & & & & $x$ & & & & 1.0 & & & \\
\hline & No. 1 Outer & & & & & $x$ & $x$ & & & $x$ & & & & \\
\hline & No. 2 Inner & & $x$ & & & & & & & & 0.25 & & & \\
\hline & No. 2 Outer & $x$ & & & & & & & & & 0.25 & $x$ & & \\
\hline & No. 3 Inner & & & $x$ & & & & & & & 0.25 & & & \\
\hline & No. 3 Outer & & $x$ & & & & $x$ & & & & 0.25 & $x$ & & \\
\hline \multicolumn{15}{|c|}{ TOTALS } \\
\hline Inners & 24 & 18 & 3 & 3 & 0 & 0 & 2 & 1 & 2 & 0 & $0.25-12.0$ & 0 & 0 & 0 \\
\hline Outers & 26 & 4 & 5 & 2 & 6 & 13 & 4 & 2 & 11 & 8 & $0.25-3.0$ & 4 & 4 & 4 \\
\hline
\end{tabular}


HNF-SD-SNF-TI-045, Rev. 0

This page intentionally left blank. 
HNF-SD-SNF-TI-045, Rev. 0

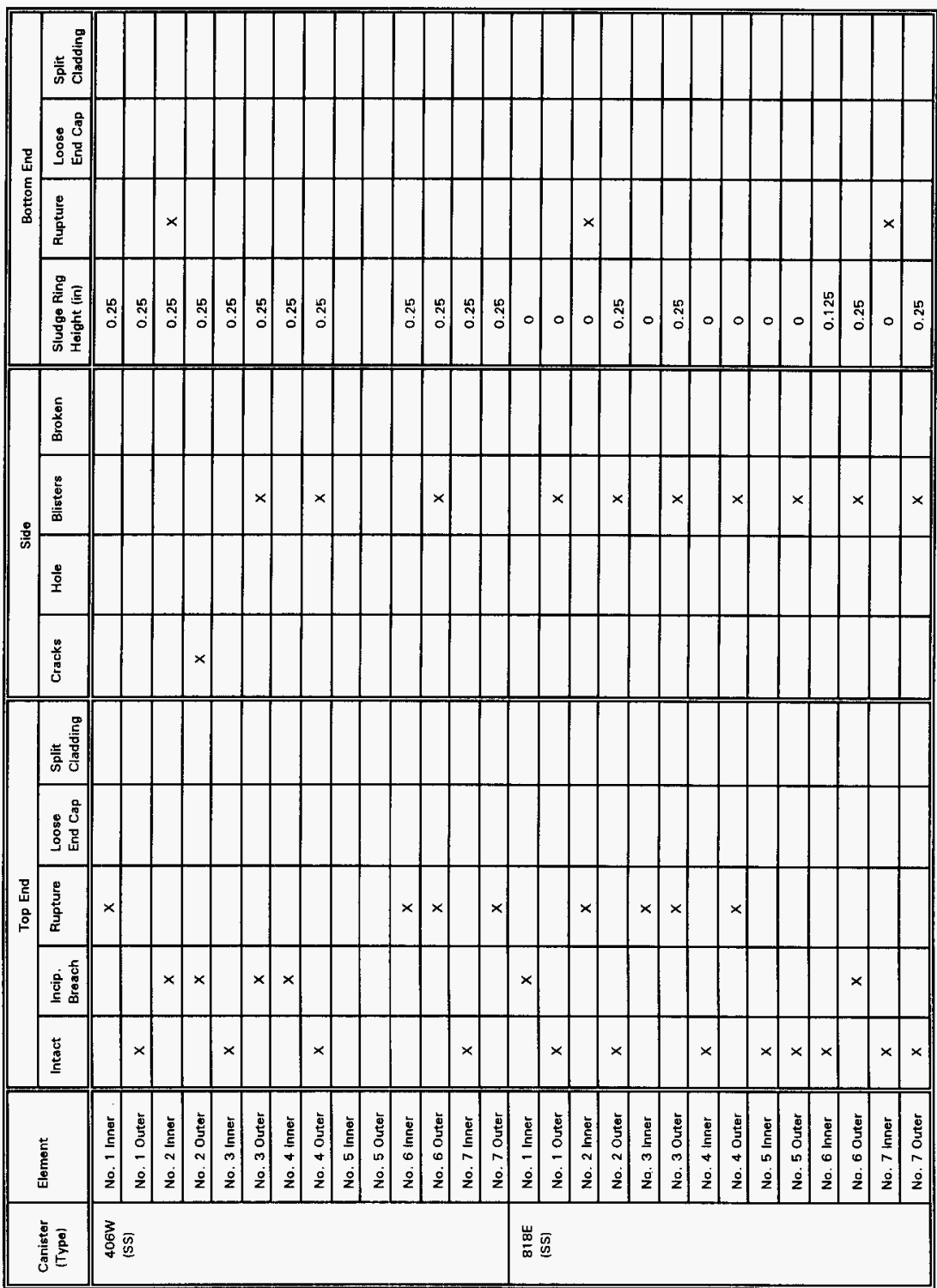


HNF-SD-SNF-TI-045, Rev, 0

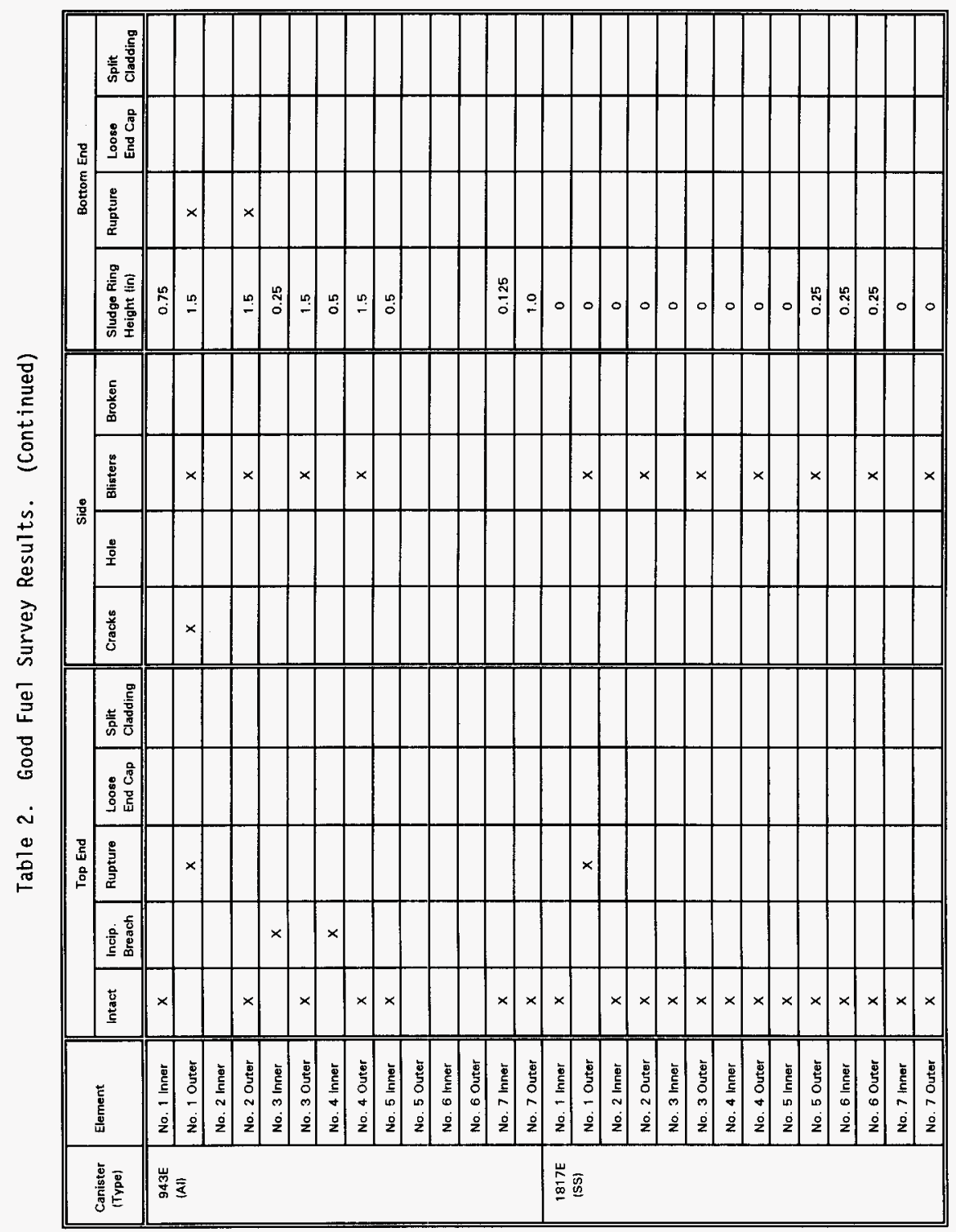


Table 2. Good Fuel Survey Results. (Continued)

\begin{tabular}{|c|c|c|c|c|c|c|c|c|c|c|c|c|c|c|}
\hline \multirow{2}{*}{$\begin{array}{l}\text { Canister } \\
\text { (Typel }\end{array}$} & \multirow{2}{*}{ Element } & \multicolumn{5}{|c|}{ Top End } & \multicolumn{4}{|c|}{ Side } & \multicolumn{4}{|c|}{ Bottom End } \\
\hline & & Intact & $\begin{array}{l}\text { Incip. } \\
\text { Breach }\end{array}$ & Rupture & $\begin{array}{l}\text { Loose } \\
\text { End Cap }\end{array}$ & $\begin{array}{l}\text { Split } \\
\text { Cladding }\end{array}$ & Cracks & Hole & Blisters & Broken & $\begin{array}{l}\text { Sludge Ring } \\
\text { Height (in) }\end{array}$ & Rupture & $\begin{array}{l}\text { Loose } \\
\text { End Cap }\end{array}$ & $\begin{array}{l}\text { Split } \\
\text { Cladding }\end{array}$ \\
\hline \multirow{14}{*}{$\begin{array}{l}\text { 1819w } \\
\text { (sS) }\end{array}$} & No. 1 Inner & $x$ & & & & & & & & & 0 & & & \\
\hline & No. 1 Outer & $x$ & & & & & & & $x$ & & 0.75 & & & \\
\hline & No. 2 Inner & $x$ & & & & & & & & & 0 & & & \\
\hline & No. 2 Outer & $x$ & & & & & & & $x$ & & 0.75 & & & \\
\hline & No. 3 Inner & $x$ & & & & & & & & & 0 & & & \\
\hline & No. 3 Outer & $x$ & & & & & & & $x$ & & 0.5 & & & \\
\hline & No. 4 Inner & $x$ & & & & & & & & & 0 & & & \\
\hline & No. 4 Outer & $x$ & & & & & & & $x$ & & 0 & & & \\
\hline & \begin{tabular}{|l|l} 
No. 5 Iner \\
\end{tabular} & $x$ & & & & & & & & & 0 & & & \\
\hline & No. 5 Outer & $x$ & & & & & & & $x$ & & 0 & & & \\
\hline & No. 6 Inner & $x$ & & & & & & & & & 0 & & & \\
\hline & No. 6 Outer & $x$ & & & & & & & $x$ & & 0 & & & \\
\hline & No. 7 mner & $x$ & & & & & & & & & 0 & & & \\
\hline & No. 7 Outer & $x$ & & & & & & & & & 0 & & & \\
\hline \multirow{14}{*}{$\begin{array}{l}1829 E \\
(S S)\end{array}$} & No. $1 \mathrm{hner}$ & $x$ & & & & & & & & & 0 & & & \\
\hline & No. 1 Outer & & & & & & & & & & & & & \\
\hline & No. 2 Inner & $x$ & & & & & & & & & 0 & & & \\
\hline & No. 2 Outer & & & $x$ & & & & & & & 0.5 & & & \\
\hline & \begin{tabular}{|l|} 
No. 3 Inner \\
\end{tabular} & $x$ & & & & & & & & & 0 & & & \\
\hline & No. 3 Outer & $x$ & & & & & & & $x$ & & 0.125 & & & \\
\hline & \begin{tabular}{|ll} 
No. 4 Inner \\
\end{tabular} & $x$ & & & & & & & & & 0 & & & \\
\hline & No. 4 Outer & $x$ & & & & & & & & & 0 & & & \\
\hline & No. 5 Inner & $x$ & & & & & & & & & 0 & & & \\
\hline & No. 5 Outer & $x$ & & & & & & & $x$ & & 0 & & & \\
\hline & No. 6 lnner & & & $x$ & & & & & & & 0 & & & \\
\hline & No. 6 Outer & & & $x$ & & & & & $x$ & & 0.5 & & & \\
\hline & No. 7 inner & $x$ & & & & & & & & & 0 & & & \\
\hline & No. 7 Outer & & $x$ & & & & & & $x$ & & 0 & & & \\
\hline
\end{tabular}


Table 2. Good Fuel Survey Results. (Continued)

\begin{tabular}{|c|c|c|c|c|c|c|c|c|c|c|c|c|c|c|}
\hline \multirow{2}{*}{$\begin{array}{l}\text { Canister } \\
\text { (Type) }\end{array}$} & \multirow{2}{*}{ Element } & \multicolumn{5}{|c|}{ Top End } & \multicolumn{4}{|c|}{ Side } & \multicolumn{4}{|c|}{ Bottom End } \\
\hline & & Intact & $\begin{array}{l}\text { Incip. } \\
\text { Breach }\end{array}$ & Rupture & $\begin{array}{l}\text { Loose } \\
\text { End Cap }\end{array}$ & $\begin{array}{l}\text { Split } \\
\text { Cladding }\end{array}$ & Cracks & Hole & Blisters & Broken & $\begin{array}{l}\text { Sludge Ring } \\
\text { Height (in) }\end{array}$ & Rupture & $\begin{array}{l}\text { Loose } \\
\text { End Cap }\end{array}$ & $\begin{array}{l}\text { Split } \\
\text { Cladding }\end{array}$ \\
\hline \multirow{14}{*}{$\begin{array}{l}1866 \mathrm{~W} \\
\text { (SS) }\end{array}$} & No. 1 Inner & $x$ & & & & & & & & & 0 & & & \\
\hline & No. I Outer & $x$ & & & & & & & $x$ & & 0 & & & \\
\hline & No. 2 Inner & $x$ & & & & & & & & & 0.125 & & & \\
\hline & No. 2 Outer & $x$ & & & & & & & $x$ & & 0.25 & & & \\
\hline & No, 3 inner & $x$ & & & & & & & & & 0.25 & & & \\
\hline & No. 3 Outer & $x$ & & & & & & & & & 0.25 & & & \\
\hline & No. 4 Inner & $x$ & & & & & & & & & 0.25 & & & \\
\hline & No. 4 Outer & $x$ & & & & & & & $x$ & & 0.25 & & & \\
\hline & No. 5 Inner & $x$ & & & & & & & & & 0.25 & & & \\
\hline & No. 5 Outer & & & $x$ & & & & & $x$ & & 0.125 & & & \\
\hline & No. 6 Inner & & & & & & & & & & & & & \\
\hline & No. 6 Outer & & & $x$ & & & & & & & 0.125 & & & \\
\hline & No. 7 inner & & $x$ & & & & & & & & 0.25 & & & \\
\hline & No. 7 Outer & & $x$ & & & & & & $x$ & & 0.25 & & & \\
\hline \multirow{14}{*}{$\begin{array}{l}2071 \mathrm{E} \\
\text { (SS) }\end{array}$} & No. 1 Inner & & $x$ & & & & & & & & 0.125 & & & \\
\hline & No. 1 Outer & & & $x$ & & & & & $x$ & & 0.25 & & & \\
\hline & No. 2 Inner & $x$ & & & & & & & & & 0.125 & & & \\
\hline & No. 2 Outer & & & $x$ & & & & & $x$ & & 0.25 & & & \\
\hline & No. 3 Inner & $x$ & & & & & & & & & 0.125 & & & \\
\hline & No. 3 Outer & $x$ & & & & & & & $x$ & & 0.25 & & & \\
\hline & No. 4 Inner & $x$ & & & & & & & & & 0.125 & & & \\
\hline & No. 4 Outer & & & $x$ & & & & & & & 0.25 & & & \\
\hline & No. 5 inner & $x$ & & & & & & & & & 0.125 & & & \\
\hline & No. 5 Outer & & & $x$ & & & & & $x$ & & 0.25 & & & \\
\hline & No. 6 inner & $x$ & & & & & & & & & 0.125 & & & \\
\hline & No. 6 Outer & & $x$ & & & & & & & & 0.25 & & & \\
\hline & No., 7 Inner & $x$ & & & & & & & & & 0.125 & & & \\
\hline & No. 7 Outer & $x$ & & & & & & & & & 0.25 & & & \\
\hline
\end{tabular}


Table 2. Good Fuel Survey Results. (Continued)

\begin{tabular}{|c|c|c|c|c|c|c|c|c|c|c|c|c|c|c|}
\hline \multirow{2}{*}{$\begin{array}{l}\text { Canister } \\
\text { (Type) }\end{array}$} & \multirow{2}{*}{ Element } & \multicolumn{5}{|c|}{ Top End } & \multicolumn{4}{|c|}{ Side } & \multicolumn{4}{|c|}{ Bottom End } \\
\hline & & Intact & $\begin{array}{l}\text { Incip. } \\
\text { Breach }\end{array}$ & Rupture & $\begin{array}{l}\text { Loose } \\
\text { End Cap }\end{array}$ & $\begin{array}{l}\text { Split } \\
\text { Cladding }\end{array}$ & Cracks & Hole & Blisters & Broken & $\begin{array}{l}\text { Siudge Ring } \\
\text { Height (in) }\end{array}$ & Rupture & $\begin{array}{l}\text { Loose } \\
\text { End Cap }\end{array}$ & $\begin{array}{l}\text { Split } \\
\text { Cladding }\end{array}$ \\
\hline \multirow{14}{*}{$\begin{array}{c}2233 W \\
\text { (A) }\end{array}$} & No. 1 Inner & & & & & & & & & & & & & \\
\hline & No. 1 Outer & & & & & & & & & & & & & \\
\hline & No. 2 Inner & $x$ & & & & & & & & & 0.5 & & & \\
\hline & No. 2 Outer & $x$ & & & & & & & & & 1.0 & & & \\
\hline & No. 3 Inner & & $x$ & & & & & & & & 0.25 & & & \\
\hline & No. 3 Outer & & & & & & & & & & & & & \\
\hline & No. 4 inner & $x$ & & & & & & & & & 0.5 & & & \\
\hline & No. 4 Outer & $x$ & & & & & & & $x$ & & 0.75 & $x$ & & \\
\hline & No. 5 inner & $x$ & & & & & & & & & 0.25 & & & \\
\hline & No. 5 Outer & $x$ & & & & & & & $x$ & & 0.5 & & & \\
\hline & No. 6 Inner & $x$ & & & & & & & & & 0.25 & & & \\
\hline & No. 6 Outor & $x$ & & & & & & & & & 0.5 & & & \\
\hline & No. 7 Inner & $x$ & & & & & & & & & 0.25 & & & \\
\hline & No. 7 Outer & & & $x$ & & & & & & & 0.5 & & & \\
\hline \multirow{14}{*}{$\begin{array}{l}2302 \mathrm{E} \\
\text { (SS) }\end{array}$} & No. 1 Inner & $x$ & & & & & & & & & 0 & & & \\
\hline & No. 1 Outer & $x$ & & & & & & & & & 0 & & & \\
\hline & No. 2 Inner & $x$ & & & & & & & & & 0 & & & \\
\hline & No. 2 Outer & $x$ & & & & & & & & & 0 & & & \\
\hline & No. 3 inner & $x$ & & & & & & & & & 0 & & & \\
\hline & No. 3 Outer & $x$ & & & & & & & $x$ & & 0 & & & \\
\hline & No. 4 Inner & $x$ & & & & & & & & & 0 & & & \\
\hline & No, 4 Outer & $x$ & & & & & & & $x$ & & o & & & \\
\hline & No. 5 Inner & $x$ & & & & & & & & & $\mathbf{o}$ & & & \\
\hline & No. 5 Outer & $x$ & & & & & & & & & 0 & & & \\
\hline & No. 6 Inner & $x$ & & & & & & & & & 0 & & & \\
\hline & No. 6 Outor & & $x$ & & & & & & $x$ & & 0 & & & \\
\hline & No. 7 Inner & $x$ & & & & & & & & & 0 & & & \\
\hline & No. 7 Outer & $x$ & & & & & & & & & 0 & & & \\
\hline
\end{tabular}


HNF-SD-SNF-TI-045, Rev, 0

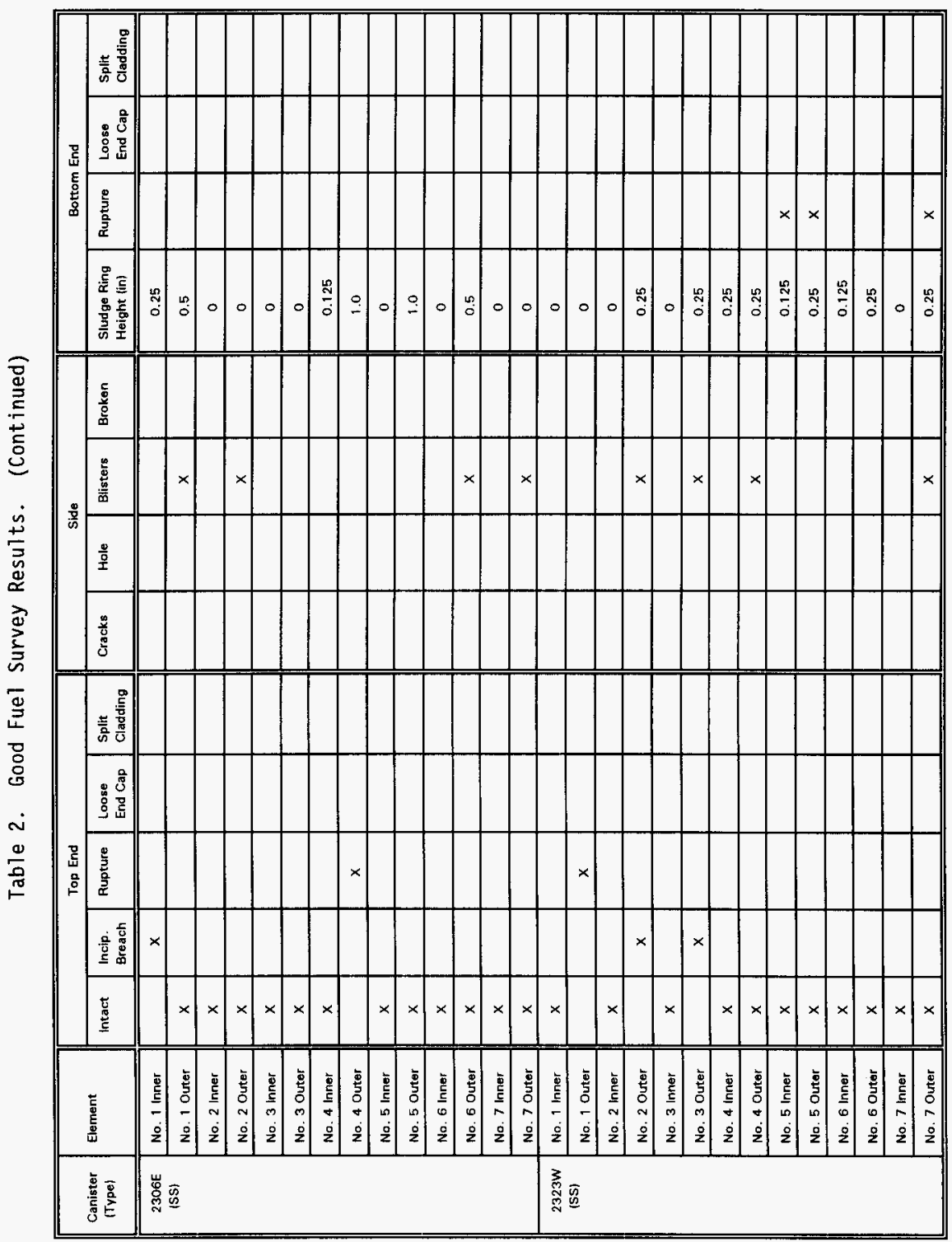


HNF-SD-SNF-TI-045, Rev. 0

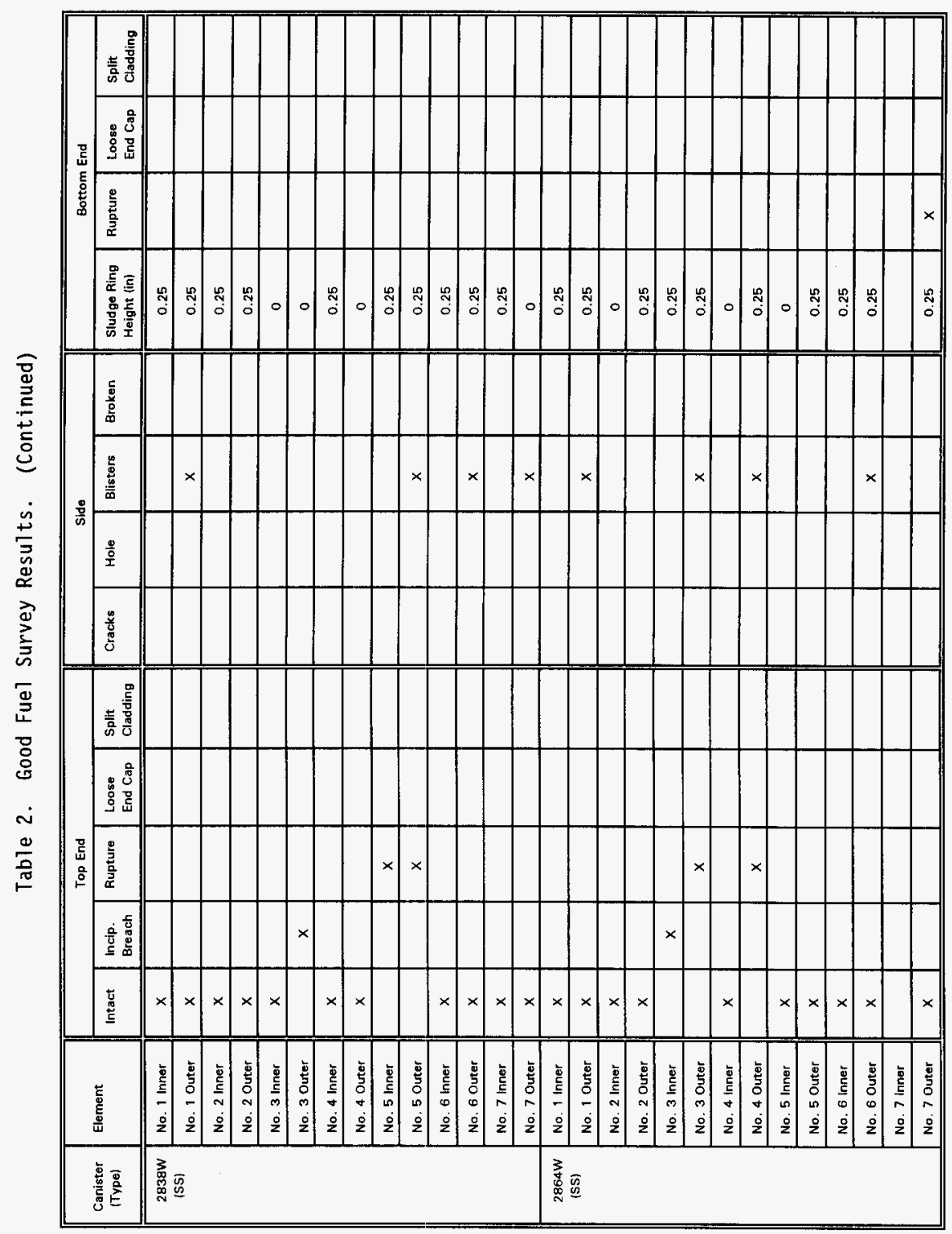


Table 2. Good Fuel Survey Results. (Continued)

\begin{tabular}{|c|c|c|c|c|c|c|c|c|c|c|c|c|c|c|}
\hline \multirow[b]{2}{*}{$\begin{array}{l}\text { Canister } \\
\text { (Type) }\end{array}$} & \multirow{2}{*}{ Element } & \multicolumn{5}{|c|}{ Top End } & \multicolumn{4}{|c|}{ Side } & \multicolumn{4}{|c|}{ Bottom End } \\
\hline & & Intact & $\begin{array}{l}\text { Incip. } \\
\text { Breach }\end{array}$ & Rupture & $\begin{array}{l}\text { Loose } \\
\text { End Cap }\end{array}$ & $\begin{array}{l}\begin{array}{l}\text { Split } \\
\text { cladding }\end{array} \\
\end{array}$ & Cracks & Holo & Bisters & Broken & $\begin{array}{l}\text { Sludge Ring } \\
\text { Height (in) }\end{array}$ & Rupture & $\begin{array}{l}\text { Loose } \\
\text { End Cap }\end{array}$ & $\begin{array}{l}\text { Split } \\
\text { Cladding }\end{array}$ \\
\hline \multirow{14}{*}{$\begin{array}{l}3574 \mathrm{E} \\
\text { (SS) }\end{array}$} & No. 1 Inner & & & $x$ & & & & & & & 0.125 & & & \\
\hline & No. 1 Outer & & $x$ & & & & & $x$ & $x$ & & 0.5 & & & \\
\hline & No. 2 inner & $x$ & & & & & & & & & 0.25 & & & \\
\hline & No. 2 Outer & & & $x$ & & & & & & & 0.75 & & & \\
\hline & No. 3 Inner & $x$ & & & & & & & & & 0.25 & & & \\
\hline & No. 3 Outer & & $x$ & & & & & & $x$ & & 1.0 & & & \\
\hline & No. 4 Inner & & & $x$ & & & & & & & 0.25 & & & \\
\hline & No. 4 Outer & & & $x$ & & & & & $x$ & & 0.75 & & & \\
\hline & No. 5 Inner & $x$ & & & & & & & & & 0.25 & & & \\
\hline & No. 5 Outer & $x$ & & & & & & & & & 0.5 & $x$ & & \\
\hline & No. 6 Inner & $x$ & & & & & & & & & 0.125 & & & \\
\hline & No. 6 Outer & & & $x$ & & & & & & & 0 & & & \\
\hline & No. 7 Inner & $x$ & & & & & & & & & 0.25 & & & \\
\hline & No. 7 Outer & & $x$ & & & & & & & & 0.5 & & & \\
\hline \multirow{14}{*}{$\begin{array}{l}3764 \mathrm{~W} \\
\text { (SS) }\end{array}$} & No. 1 Inner & $x$ & & & & & & & & & 0 & $x$ & & \\
\hline & No. 1 Outer & $x$ & & & & & & & $x$ & & 0 & & & \\
\hline & No. 2 Inner & $x$ & & & & & & & & & 0.25 & & & \\
\hline & No. 2 Outer & $x$ & & & & & & & & & 0.25 & & & \\
\hline & No. 3 Inner & & $x$ & & & & & & & & 0.25 & & & \\
\hline & No. 3 Outer & $x$ & & & & & & & & & 0.25 & & & \\
\hline & No. 4 Inner & $x$ & & & & & & & & & 0 & & & \\
\hline & No. 4 Outer & $x$ & & & & & & & $x$ & & 0.25 & & & \\
\hline & No. 5 kner & $x$ & & & & & & & & & 0 & & & \\
\hline & No. 5 Outer & $x$ & & & & & & & & & 0.25 & & & \\
\hline & No. 6 Inner & $x$ & & & & & & & & & 0.25 & & & \\
\hline & No. 6 Outer & $x$ & & & & & & & & & 0.25 & & & \\
\hline & No. 7 Inner & $x$ & & & & & & & & & 0 & & & \\
\hline & No. 7 Outer & & $x$ & & & & & & $x$ & & 0.25 & & & \\
\hline
\end{tabular}


Table 2. Good Fuel Survey Results. (Continued)

\begin{tabular}{|c|c|c|c|c|c|c|c|c|c|c|c|c|c|c|}
\hline \multirow[b]{2}{*}{$\begin{array}{l}\text { Canister } \\
\text { (Type) }\end{array}$} & \multirow{2}{*}{ Element } & \multicolumn{5}{|c|}{ Top End } & \multicolumn{4}{|c|}{ Side } & \multicolumn{4}{|c|}{ Bottom End } \\
\hline & & Intact & $\begin{array}{l}\text { Incip. } \\
\text { Breach }\end{array}$ & Rupture & $\begin{array}{l}\text { Loose } \\
\text { End Cap }\end{array}$ & $\begin{array}{l}\text { Split } \\
\text { Cladding }\end{array}$ & Cracks & Hole & Blisters & Broken & $\begin{array}{l}\text { Sludge Ring } \\
\text { Height (in) }\end{array}$ & Rupture & $\begin{array}{l}\text { Loose } \\
\text { End Cap }\end{array}$ & $\begin{array}{l}\text { Split } \\
\text { Cladding }\end{array}$ \\
\hline \multirow{14}{*}{$\begin{array}{l}4156 \mathrm{~W} \\
\text { (Ai) }\end{array}$} & No. 1 Inner & $x$ & & & & & & & & & 0.25 & & & \\
\hline & No. 1 Outer & $x$ & & & & & & & $x$ & & 1.5 & & & \\
\hline & No. 2 Inner & $x$ & & & & & & & & & 0.5 & & & \\
\hline & No. 2 Outer & & & $x$ & & & & & $x$ & & 2.0 & & & \\
\hline & No. 3 Inner & $x$ & & & & & & & & & 1.0 & & & \\
\hline & No. 3 Outer & & $x$ & & & & $x$ & & $x$ & & 2.0 & & & \\
\hline & No. 4 Inner & $x$ & & & & & & & & & 1.0 & & & \\
\hline & No. 4 Outer & $x$ & & & & & & & $x$ & & 1.5 & & & \\
\hline & No. 5 Inner & $x$ & & & & & & & & & 0.75 & & & \\
\hline & No. 5 Outer & & & $x$ & & & & & $x$ & & 1.0 & & & \\
\hline & No. 6 Inner & $x$ & & & & & & & & & 0.5 & & & \\
\hline & No. 6 Outer & $x$ & & & & & & & & & 1.0 & & & \\
\hline & No. 7 inner & $x$ & & & & & & & & & 1.0 & & & \\
\hline & No. 7 Outer & $x$ & & & & & & & & & 0.75 & & & $x$ \\
\hline \multirow{14}{*}{$\begin{array}{l}4643 \mathrm{E} \\
\text { (SS) }\end{array}$} & No. 1 Inner & & $x$ & & & & & & & & 0 & & & \\
\hline & No. 1 Outer & & & $x$ & & & & & & & 0 & & & \\
\hline & No. 2 Inner & $x$ & & & & & & & & & 0 & & & \\
\hline & No. 2 Outer & & & $x$ & & & & & & & 0 & & & \\
\hline & No. 3 Inner & $x$ & & & & & & & & & 0 & & & \\
\hline & No. 3 Outer & $x$ & & & & & & & $x$ & & 0 & & & \\
\hline & No. 4 Inner & $x$ & & & & & & & & & 0 & & & \\
\hline & No. 4 Outer & $x$ & & & & & & & & & 0 & & & \\
\hline & No. 5 Inner & $x$ & & & & & & & & & 0 & & & \\
\hline & No. 5 Outer & & & $x$ & & & & & $x$ & & 0 & & & \\
\hline & No. 6 Inner & $x$ & & & & & & & & & 0 & & & \\
\hline & No. 6 Outer & $x$ & & & & & & & & & 0 & & & \\
\hline & No. 7 Inner & & & $x$ & & & & & & & 0 & & & \\
\hline & No. 7 Outer & & $x$ & & & & & & $x$ & & 0 & & & \\
\hline
\end{tabular}


Table 2. Good Fuel Survey Results. (Continued)

\begin{tabular}{|c|c|c|c|c|c|c|c|c|c|c|c|c|c|c|}
\hline \multirow[b]{2}{*}{$\begin{array}{l}\text { Canister } \\
\text { (Type) }\end{array}$} & \multirow{2}{*}{ Element } & \multicolumn{5}{|c|}{ Top End } & \multicolumn{4}{|c|}{ Side } & \multicolumn{4}{|c|}{ Bottom End } \\
\hline & & Intact & $\begin{array}{l}\text { Incip. } \\
\text { Breach }\end{array}$ & Rupture & $\begin{array}{l}\text { Loose } \\
\text { End Cap }\end{array}$ & $\begin{array}{l}\text { Split } \\
\text { Cladding }\end{array}$ & Cracks & Hole & Blisters & Broken & $\begin{array}{l}\text { Sludge Ring } \\
\text { Height (in) }\end{array}$ & Rupture & $\begin{array}{l}\text { Loose } \\
\text { End Cap }\end{array}$ & $\begin{array}{l}\text { Split } \\
\text { Cladding }\end{array}$ \\
\hline \multirow{14}{*}{$\begin{array}{l}4727 \mathrm{~W} \\
\text { (SS) }\end{array}$} & No. 1 Inner & $x$ & & & & & & & & & 0.25 & & & \\
\hline & No. 1 Outer & $x$ & & & & & & & $x$ & & 0.25 & & & \\
\hline & No. 2 inner & $x$ & & & & & & & & & 0.25 & & & \\
\hline & No. 2 Outer & & $x$ & & & & & & & & 0.5 & & & \\
\hline & No. 3 Inner & $x$ & & & & & & & & & 0.5 & & & $x$ \\
\hline & No. 3 Outer & & & & & & & & & & & & & \\
\hline & No. 4 Inner & $x$ & & & & & & & & & 0.25 & & & \\
\hline & No. 4 Outer & & $x$ & & & & & & & & 0.25 & & $x$ & \\
\hline & No. 5 Inner & $x$ & & & & & & & & & 0.25 & & & \\
\hline & No. 5 Outer & & & & & & & & & & & & & \\
\hline & No. 6 Inner & & $x$ & & & & & & & & 0.5 & & & \\
\hline & No. 6 Outer & & $x$ & & & & & & $x$ & & 0.5 & & & \\
\hline & No. 7 Inner & $x$ & & & & & & & & & 0.5 & & & \\
\hline & No. 7 Outer & & $x$ & & & & & & & & 0.5 & $x$ & & \\
\hline \multirow{14}{*}{$\begin{array}{l}4804 W \\
\text { (SS) }\end{array}$} & No. 1 Inner & $x$ & & & & & & & & & 1.0 & & & \\
\hline & No. 1 Outer & & & $x$ & & & & & & & 1.0 & & & \\
\hline & No. 2 Inner & $x$ & & & & & & & & & 1.0 & & & \\
\hline & No. 2 Outer & $x$ & & & & & & & $x$ & & 1.0 & & & \\
\hline & No. 3 Inner & $x$ & & & & & & & & & 0.5 & & & \\
\hline & No. 3 Outer & $x$ & & & & & & & $x$ & & 1.0 & & & \\
\hline & No. 4 Inner & $x$ & & & & & & & & & 0.5 & & & \\
\hline & No. 4 Outer & & & $x$ & & & & & $x$ & & 1.0 & & & \\
\hline & No. 5 Inner & $x$ & & & & & & & & & 1.0 & & & \\
\hline & No. 5 Outer & $x$ & & & & & & & $x$ & & 1.0 & & & \\
\hline & No. 6 Inner & $x$ & & & & & & & & & 1.0 & & & \\
\hline & No. 6 Outer & $x$ & & & & & & & $x$ & & 1.0 & & & \\
\hline & No. 7 Inner & & $x$ & & & & & & & & 0.5 & & & \\
\hline & No. 7 Outer & $x$ & & & & & & & & & 1.0 & & & \\
\hline
\end{tabular}


HNF-SD-SNF-TI-045, Rev. 0

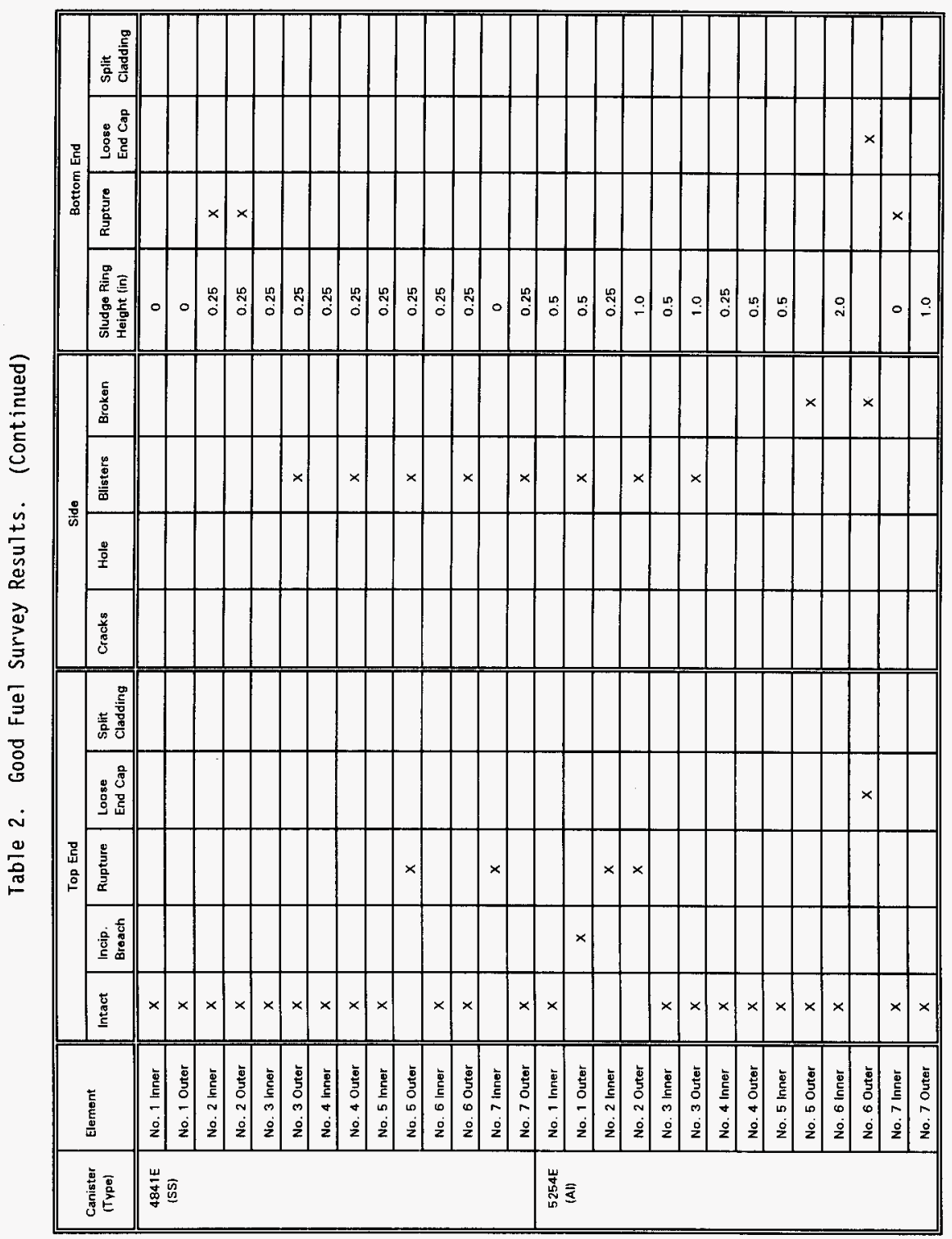


HNF-SD-SNF-TI-045, Rev. 0

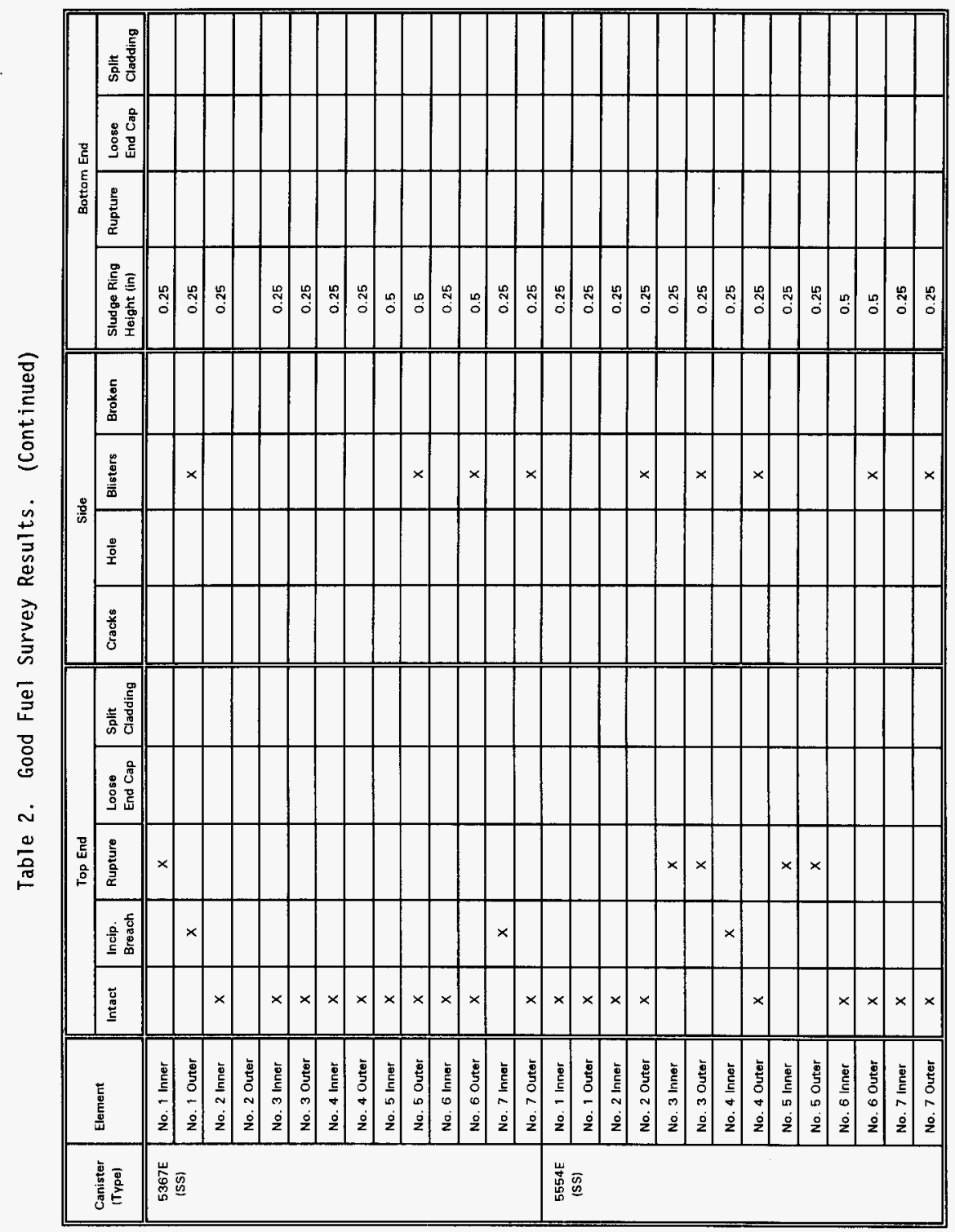


Table 2. Good Fuel Survey Results. (Continued)

\begin{tabular}{|c|c|c|c|c|c|c|c|c|c|c|c|c|c|c|}
\hline \multirow[b]{2}{*}{$\begin{array}{l}\text { Canister } \\
\text { (Type) }\end{array}$} & \multirow{2}{*}{ Element } & \multicolumn{5}{|c|}{ Top End } & \multicolumn{4}{|c|}{ Sido } & \multicolumn{4}{|c|}{ Bottom End } \\
\hline & & Intact & $\begin{array}{l}\text { Incip. } \\
\text { Breach }\end{array}$ & Rupture & $\begin{array}{l}\text { Loose } \\
\text { End Cap }\end{array}$ & $\begin{array}{l}\text { Split } \\
\text { Cladding }\end{array}$ & Cracks & Hole & Blisters & Broken & $\begin{array}{l}\text { Sludge Ring } \\
\text { Height (in) }\end{array}$ & Rupture & $\begin{array}{l}\text { Loose } \\
\text { End Cap }\end{array}$ & $\begin{array}{l}\text { Split } \\
\text { Cladding }\end{array}$ \\
\hline \multirow{14}{*}{$\begin{array}{l}5565 \mathrm{~W} \\
\text { (SS) }\end{array}$} & No. 1 Inner & $x$ & & & & & & & & & 0.25 & & & \\
\hline & No. 1 Outer & $x$ & & & & & & & $x$ & & 0.25 & & & \\
\hline & No. 2 Inner & $x$ & & & & & & & & & 0.25 & & & \\
\hline & No. 2 Outer & $x$ & & & & & & & $x$ & & 0.25 & & & \\
\hline & No. 3 Inner & & & $x$ & & & & & & & 0.75 & & & \\
\hline & No. 3 Outer & & $x$ & & & & & & $x$ & & 0.25 & & & \\
\hline & No. 4 Inner & $x$ & & & & & & & & & 0.5 & & & \\
\hline & No. 4 Outer & $x$ & & & & & & & $x$ & & 0.5 & & & \\
\hline & No. 5 Inner & $x$ & & & & & & & & & 0.75 & & & \\
\hline & No. 5 Outer & $x$ & & & & & & & $x$ & & 0.75 & & & \\
\hline & No. 6 Inner & $x$ & & & & & & & & & 0.5 & & & \\
\hline & No. 6 Outer & & $x$ & & & & & & & & 0.5 & & & \\
\hline & No. 7 Inner & $x$ & & & & & & & & & 0.5 & & & \\
\hline & No. 7 Outer & $x$ & & & & & & & $x$ & & 0.5 & & & \\
\hline \multirow{14}{*}{$\begin{array}{l}5569 \mathrm{~W} \\
\text { (SS) }\end{array}$} & No. 1 Inner & $x$ & & & & & & & & & 0 & & & \\
\hline & No. 1 Outer & $x$ & & & & & & & $x$ & & 0 & & & \\
\hline & No. 2 Inner & $x$ & & & & & & & & & 0.25 & & & \\
\hline & No. 2 Outer & $x$ & & & & & & & $x$ & & 0.125 & & & \\
\hline & No. 3 Inner & $x$ & & & & & & & & & 0.25 & & & \\
\hline & No. 3 Outer & & & $x$ & & & & & $x$ & & 0.125 & & & \\
\hline & No. 4 Inner & & & & & & & & & & & & & \\
\hline & No. 4 Outer & & & & & & & & & & & & & \\
\hline & No. 5 inner & $x$ & & & & & & & & & 0.25 & & & \\
\hline & No. 5 Outer & $x$ & & & & & & & $x$ & & 0.125 & & & \\
\hline & No. 6 Inner & $x$ & & & & & & & & & 0 & & & \\
\hline & No. 6 Outer & & $x$ & & & & & & $x$ & & 0 & & & \\
\hline & No. 7 Inner & $x$ & & & & & & & & & 0.25 & & & \\
\hline & No. 7 Outer & $x$ & & & & & & & $x$ & & 0.125 & & & \\
\hline
\end{tabular}


Table 2. Good Fuel Survey Results. (Continued)

\begin{tabular}{|c|c|c|c|c|c|c|c|c|c|c|c|c|c|c|}
\hline \multirow{2}{*}{$\begin{array}{l}\text { Canister } \\
\text { (Type) }\end{array}$} & \multirow{2}{*}{ Element } & \multicolumn{5}{|c|}{ Top End } & \multicolumn{4}{|c|}{ Side } & \multicolumn{4}{|c|}{ Bottom End } \\
\hline & & Intact & $\begin{array}{l}\text { Incip. } \\
\text { Breach }\end{array}$ & Rupture & $\begin{array}{l}\text { Loose } \\
\text { End Cap }\end{array}$ & $\begin{array}{l}\text { Split } \\
\text { Cladding }\end{array}$ & Cracks & Hole & Blisters & Broken & $\begin{array}{l}\text { Sludge Ring } \\
\text { Height (in) }\end{array}$ & Rupture & $\begin{array}{l}\text { Loose } \\
\text { End Cap }\end{array}$ & $\begin{array}{l}\text { Split } \\
\text { Cladding }\end{array}$ \\
\hline \multirow{14}{*}{$\begin{array}{l}5616 \mathrm{~W} \\
\text { [SS) }\end{array}$} & No. 1 Inner & & & $x$ & & & & & & & 0.25 & & & \\
\hline & No. 1 Outer & $x$ & & & & & & & $x$ & & 0.25 & & & \\
\hline & No. 2 Inner & & $x$ & & & & & & & & 0.25 & & & \\
\hline & No. 2 Outer & $x$ & & & & & & & & & 0.5 & & & \\
\hline & No. 3 Inner & & $x$ & & & & & & & & 0.25 & & & \\
\hline & No. 3 Outer & $x$ & & & & & & & $x$ & & 0.5 & & & \\
\hline & No. 4 Inner & $x$ & & & & & & & & & 0.25 & & & \\
\hline & No. 4 Outer & $x$ & & & & & & & $x$ & & 0.25 & $x$ & & \\
\hline & No. 5 Inner & & & & & & & & & & & & & \\
\hline & No. 5 Outer & $x$ & & & & & & & & & 0.5 & & $x$ & \\
\hline & No. 6 Inner & & & & & & & & & & & & & \\
\hline & No. 6 Outer & $x$ & & & & & & & & & 0.5 & $x$ & & \\
\hline & No. 7 Inner & $x$ & & & & & & & & & 0.25 & & & \\
\hline & No. 7 Outer & $x$ & & & & & & & & & 0.25 & & & \\
\hline \multirow{14}{*}{$\begin{array}{l}5815 W \\
(S S)\end{array}$} & No. 1 Inner & & $x$ & & & & & & & & 0.5 & & & \\
\hline & No. 1 Outer & $x$ & & & & & & & $x$ & & 0.25 & & & \\
\hline & No. 2 mner & $x$ & & & & & & & & & 0.25 & & & \\
\hline & No. 2 Outer & & & & & & & & & & & & & \\
\hline & No. 3 inner & $x$ & & & & & & & & & 0.25 & & & \\
\hline & No. 3 Outer & $x$ & & & & & & & $x$ & & 0.25 & & & \\
\hline & No. 4 Inner & $x$ & & & & & & & & & 0.25 & & & \\
\hline & No. 4 Outer & $x$ & & & & & & & $x$ & & 0.25 & & & \\
\hline & No. 5 Inner & & $x$ & & & & & & & & 0.75 & & & \\
\hline & No. 5 Outer & & & $x$ & & & & & & & 0.5 & & & \\
\hline & No. 6 Inner & $x$ & & & & & & & & & 0.5 & $x$ & & \\
\hline & No. 6 Outer & $x$ & & & & & & & & & 0.5 & & & \\
\hline & No. 7 Inner & $x$ & & & & & & & & & 0.25 & & & \\
\hline & No. 7 Outer & $x$ & & & & & & & & & 0.25 & & & \\
\hline
\end{tabular}


HNF-SD-SNF-TI-045, Rev. 0

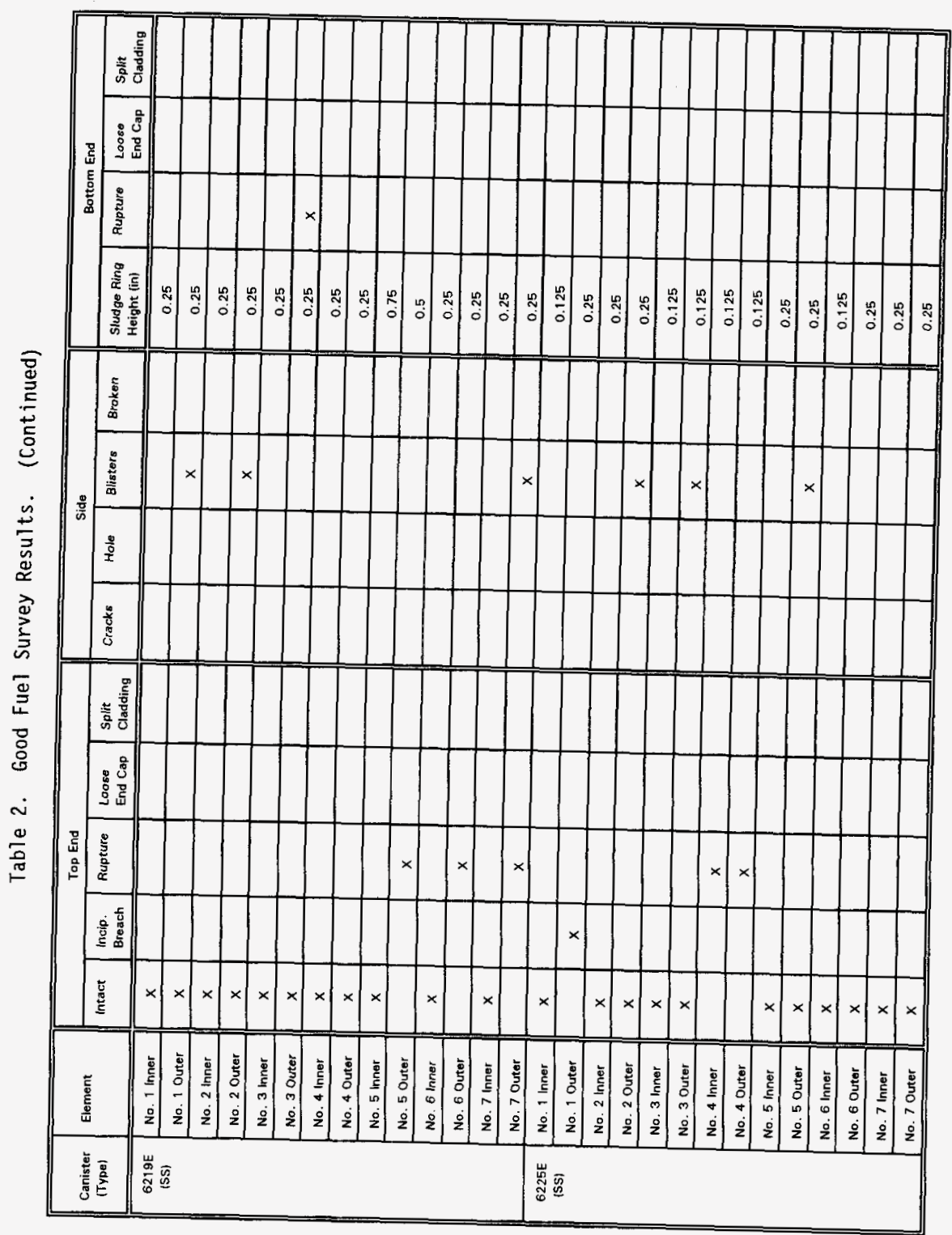


Table 2. Good Fuel Survey Results. (Continued)

\begin{tabular}{|c|c|c|c|c|c|c|c|c|c|c|c|c|c|c|}
\hline & \multirow{2}{*}{ Elements } & \multicolumn{5}{|c|}{ Top End } & \multicolumn{4}{|c|}{ Side } & \multicolumn{4}{|c|}{ Bottom End } \\
\hline & & Intact & $\begin{array}{l}\text { Incip. } \\
\text { Breach }\end{array}$ & Rupture & $\begin{array}{l}\text { Loose } \\
\text { End Cap }\end{array}$ & $\begin{array}{l}\text { Split } \\
\text { Cladding }\end{array}$ & Cracks & Hole & Blisters & Broken & $\begin{array}{l}\text { Sludge Ring } \\
\text { Height fin\} }\end{array}$ & Rupture & $\begin{array}{l}\text { Loose } \\
\text { End Cap }\end{array}$ & $\begin{array}{l}\text { Split } \\
\text { Cladding }\end{array}$ \\
\hline \multicolumn{15}{|c|}{ TOTALS } \\
\hline Inners & 201 & 164 & 20 & 17 & 0 & 0 & 0 & 0 & 0 & 0 & $0-2.0$ & 8 & 0 & 1 \\
\hline Outers & 199 & 132 & 26 & 40 & 1 & 0 & 3 & 1 & 123 & 2 & $0-1.5$ & 12 & 3 & 1 \\
\hline
\end{tabular}


HNF-SD-SNF-TI-045, Rev. 0

Table 3. Comparison of Top End and Lower End Fuel Conditions.

\begin{tabular}{||c||c|c||c|c||}
\hline \multirow{2}{*}{ Top End / Lower End } & \multicolumn{2}{c||}{ Good Fuel Survey } & \multicolumn{2}{c|}{ Bad Fuel Survey } \\
\cline { 2 - 5 } & Inners & Outers & Inners & Outers \\
\hline \hline Intact / Intact & 176 & 140 & 18 & 1 \\
\hline Intact / Ruptured & 7 & 14 & 3 & 2 \\
\hline Intact / Bad & 1 & 4 & 0 & 6 \\
\hline Ruptured / Intact & 16 & 39 & 3 & 0 \\
\hline Ruptured / Ruptured & 1 & 1 & 0 & 0 \\
\hline Ruptured / Bad & 0 & 0 & 0 & 2 \\
\hline Bad / Intact & 0 & 0 & 0 & 7 \\
\hline Bad / Ruptured & 0 & 0 & 0 & 2 \\
\hline Bad / Bad & 0 & 1 & 0 & 6 \\
\hline \hline \multicolumn{1}{|c|}{ Totals } & 201 & 199 & 24 & 26 \\
\hline
\end{tabular}


HNF-SD-SNF-TI-045, Rev. 0

This page intentionally left blank. 
Figure 1 ntact ifrer Elemerit (5569w).

\section{6-28-96 $2 \mathrm{H}$ $12: 59: 30$}

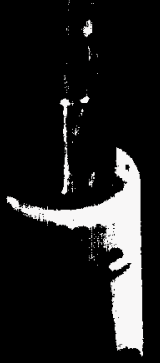


ligle? ? Incipien Broul: it Tof of an outer Element (6225t).

\section{6-24.96 2H 13:01:13}

BEST AVAILABLE COPY 


\section{INE , T: ; 1045 ReV. 0}

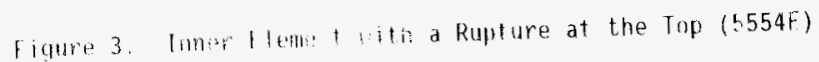

\subsection{1-96 $2 \mathrm{H}$ 21:06:12}

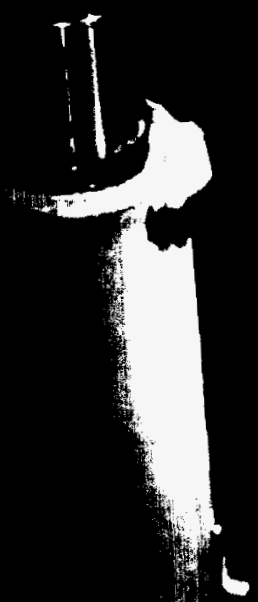


figure 4. (muter f amen w th Detached Top find Cap (2350F).

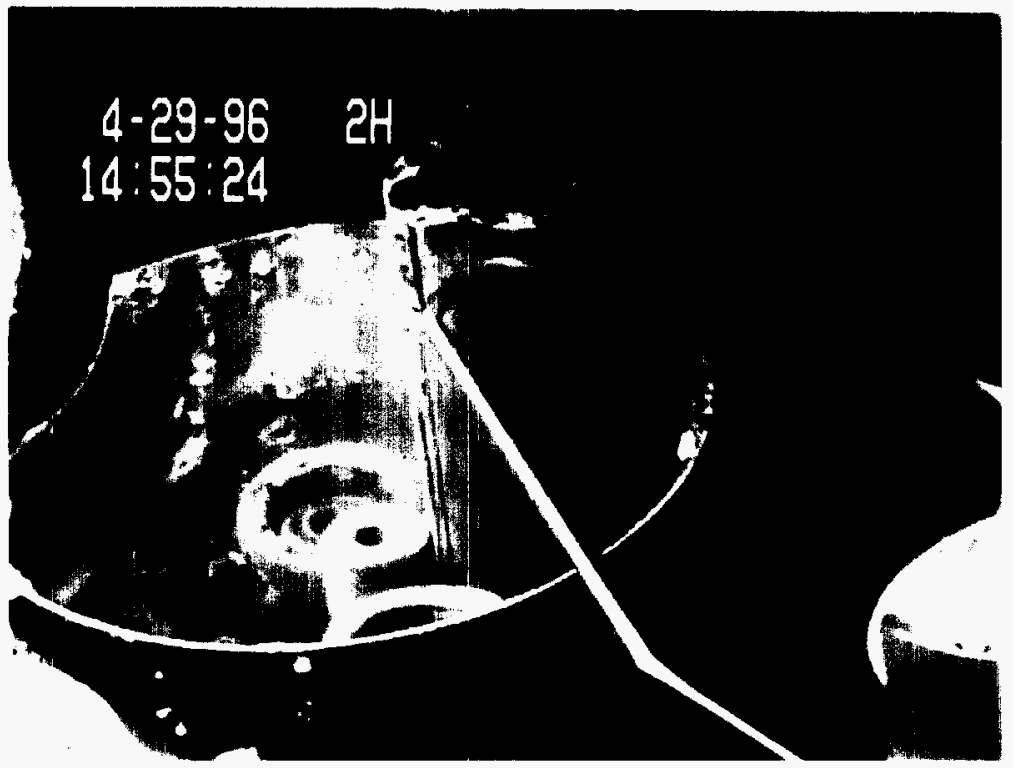




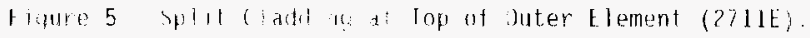

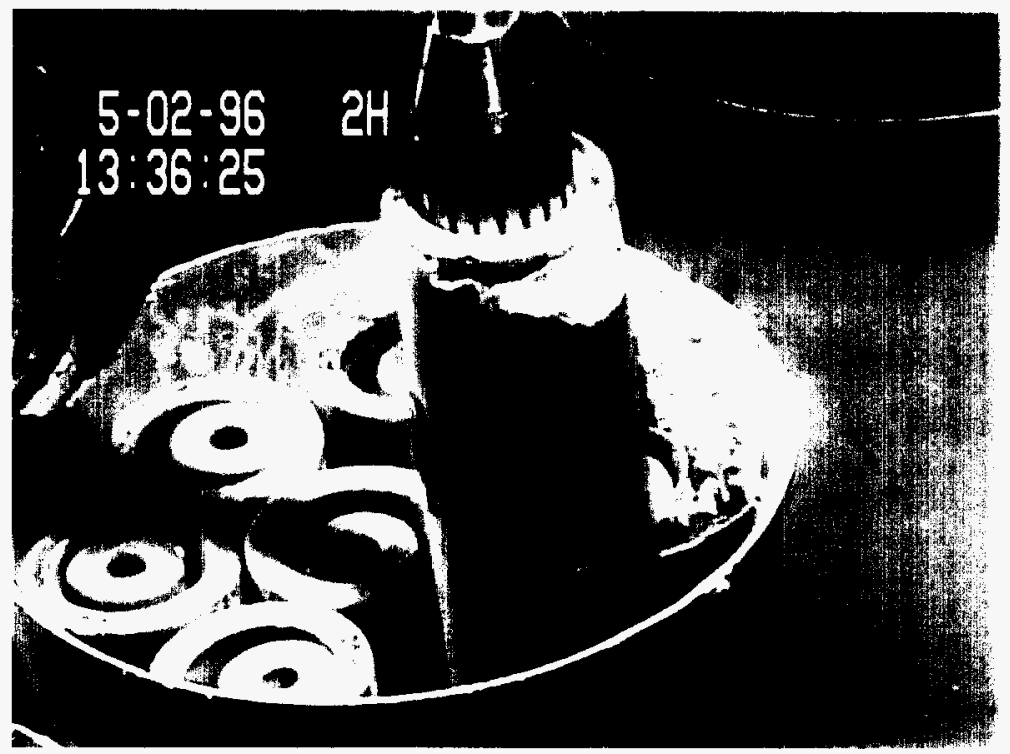

BEST AVAILRELE COPY 
Pigure 6. irak A nu be side of an Outer Flement (106w)

\section{6-25-96 $2 \mathrm{H}$ $10: 50: 53$}




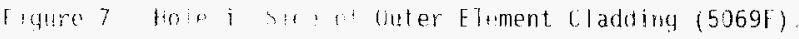

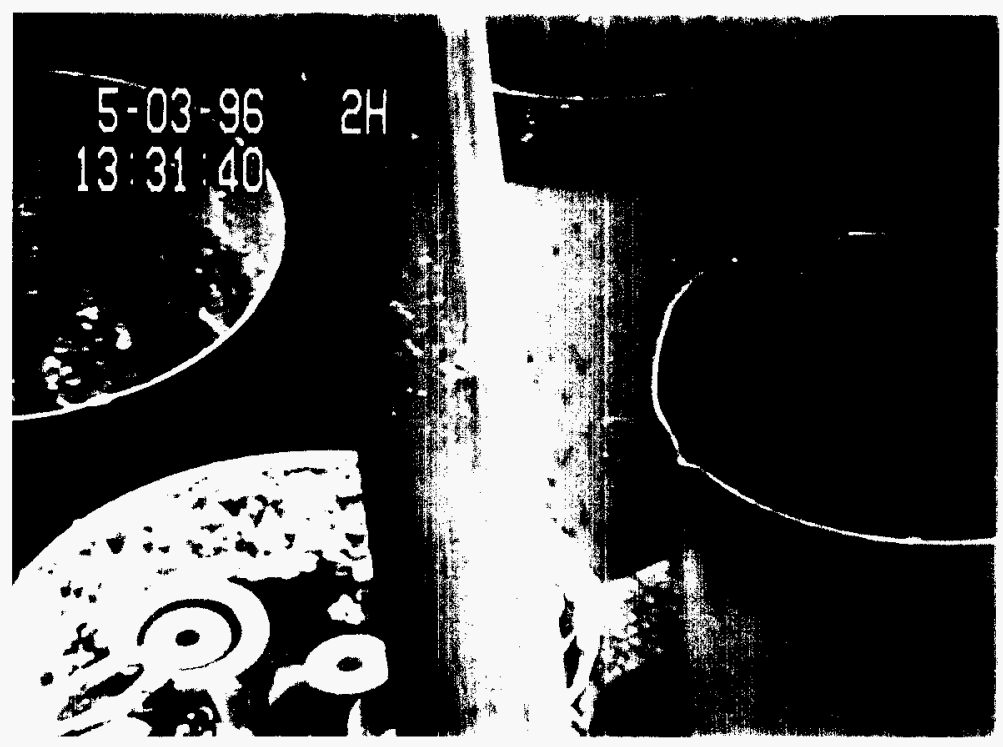




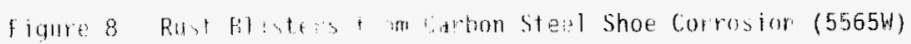

\section{6-28-96 2H 14:11:05}

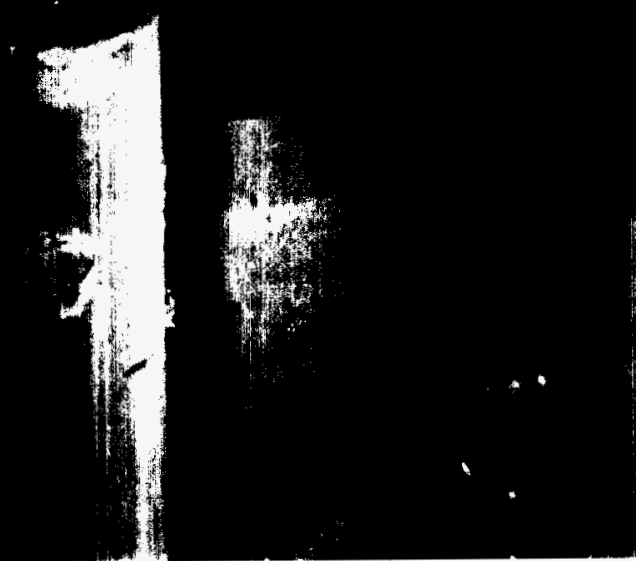




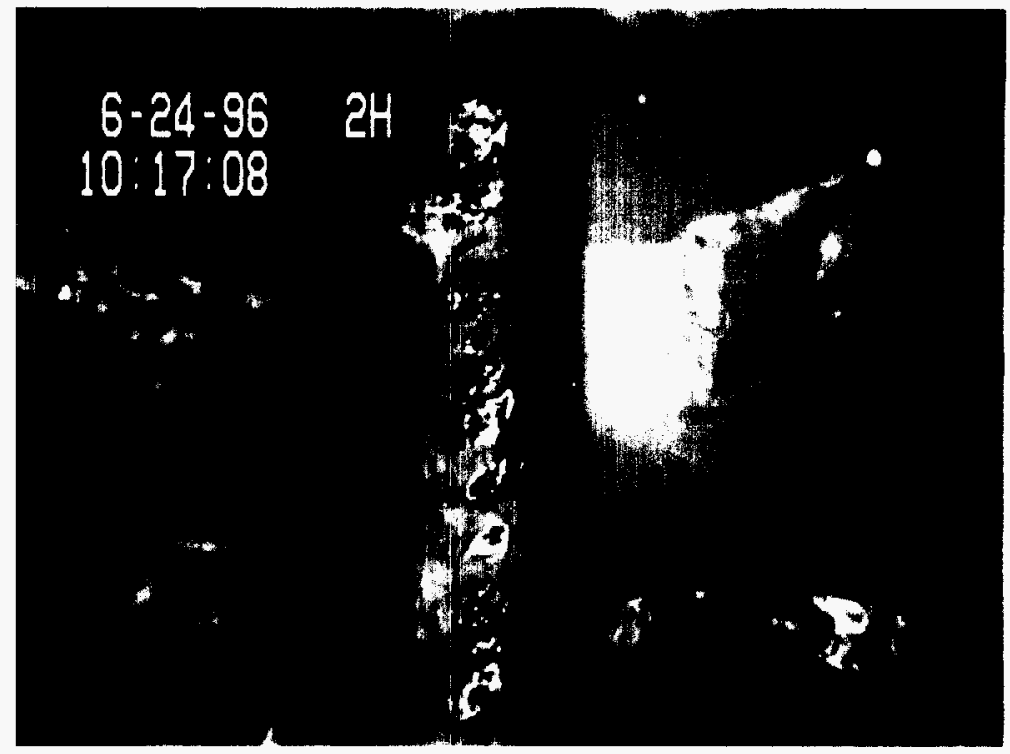


Fiqur, 10. Gliter telent Broken Near Lle Axial Midplane (5?54E).

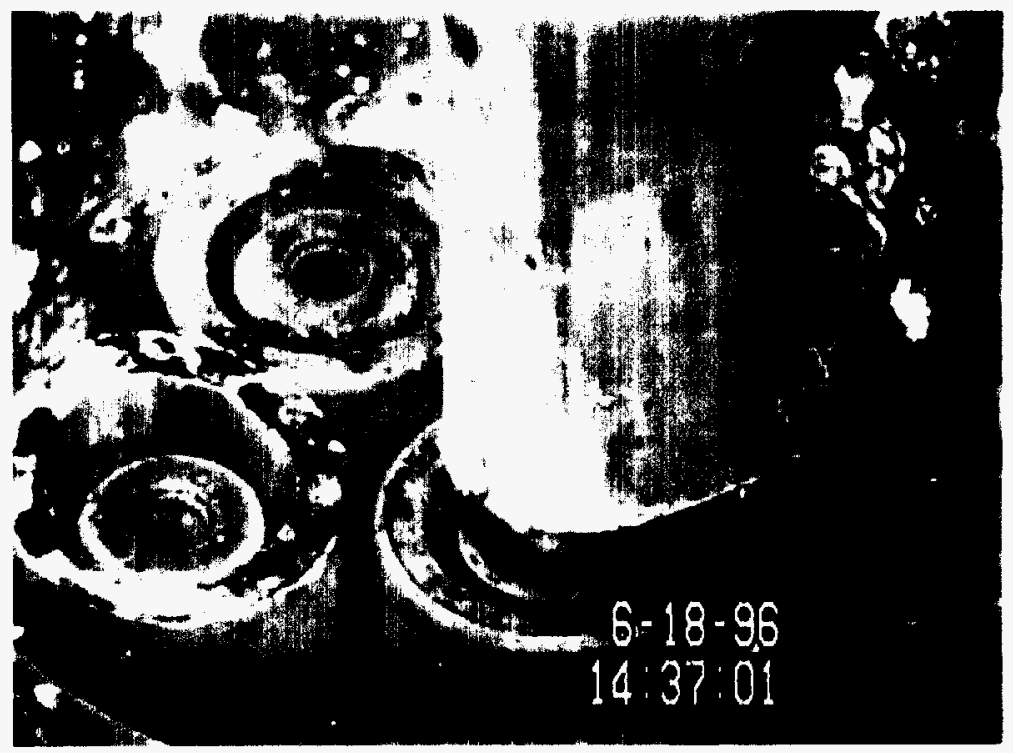

EEST FIAILPIF OOPY 
Fiqure II Sludyf Rine Arond the Bottcm of an Outer Element (943E).

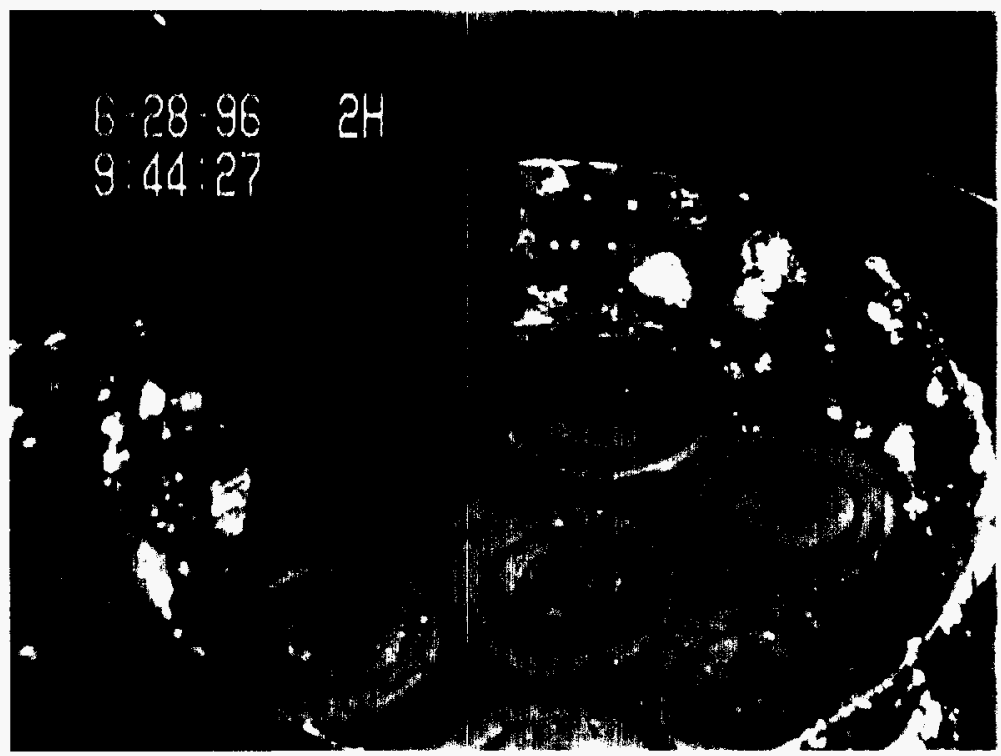




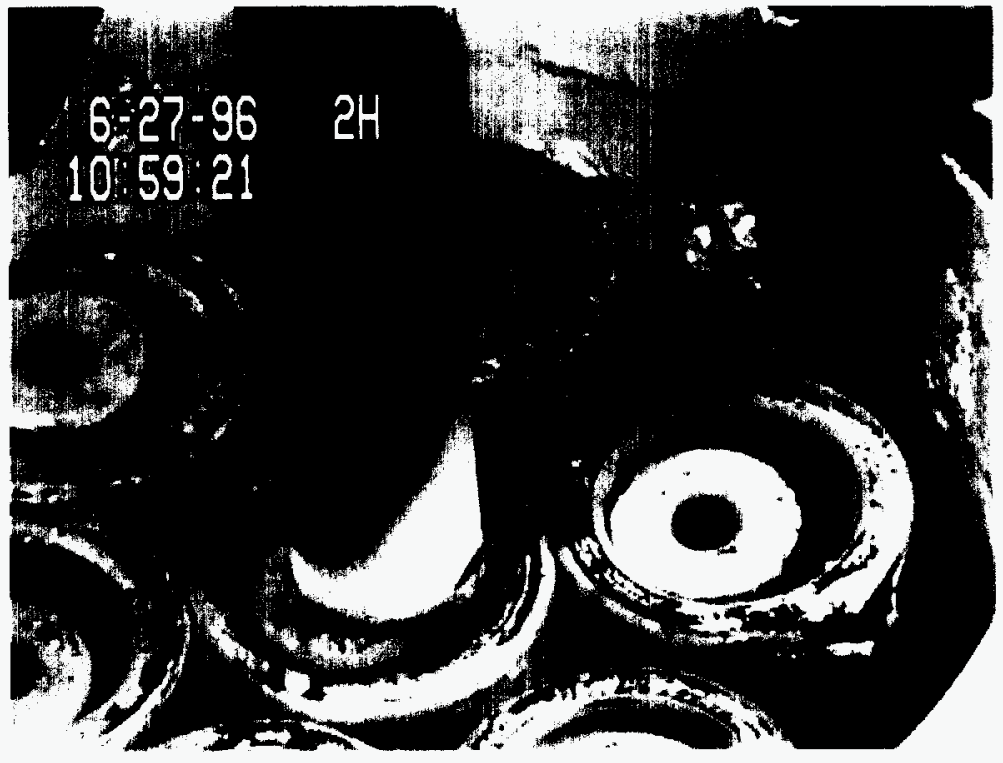


Figure 13. Out, Element with Loose End Cap and ipl $t$ ( I tudting at Bottom (5069E)

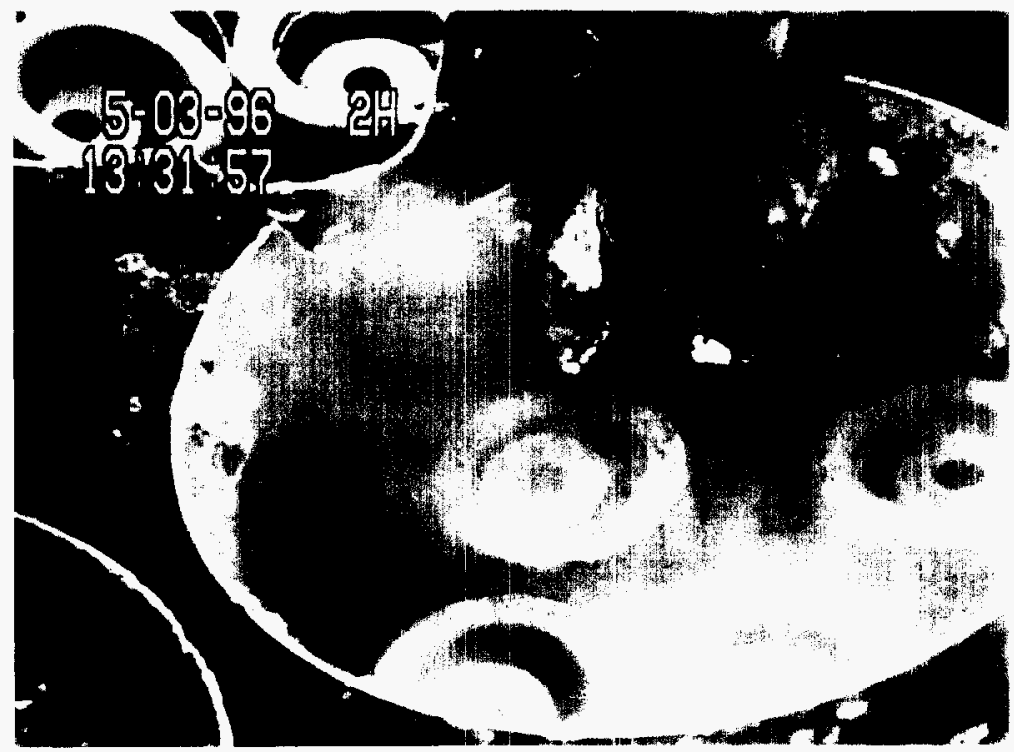




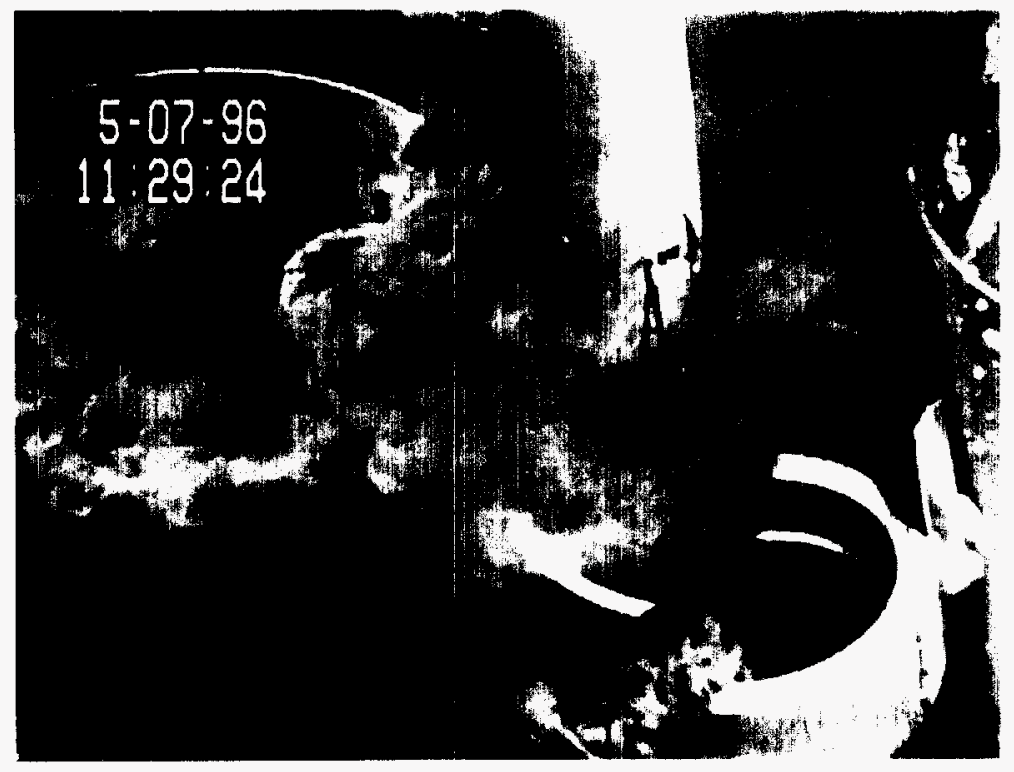




\subsubsection{6 11:18:21}
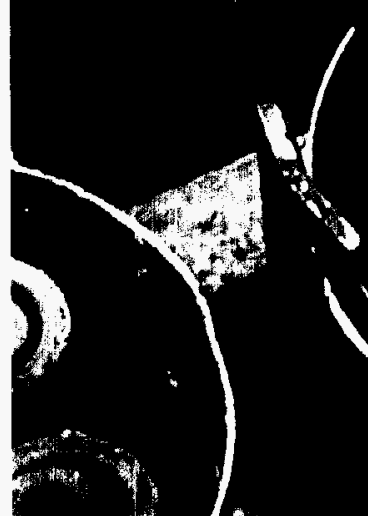
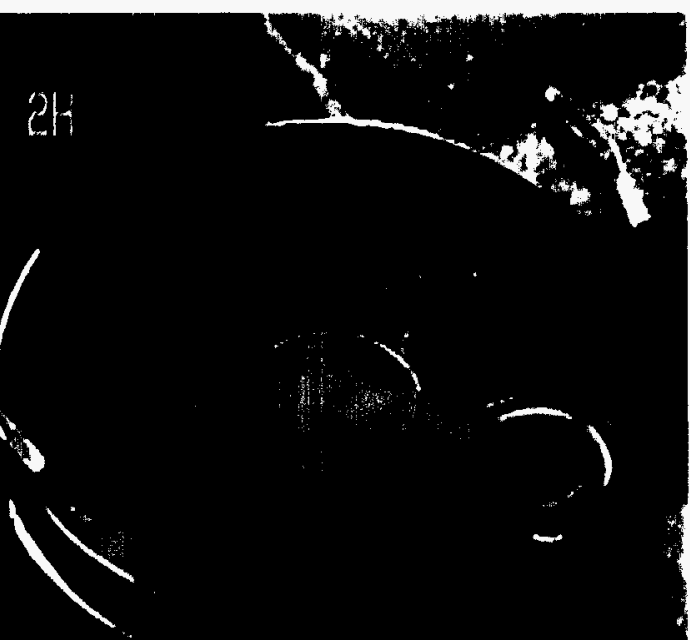
Fyure 16 Defered n? : on an outer tlement (5554)

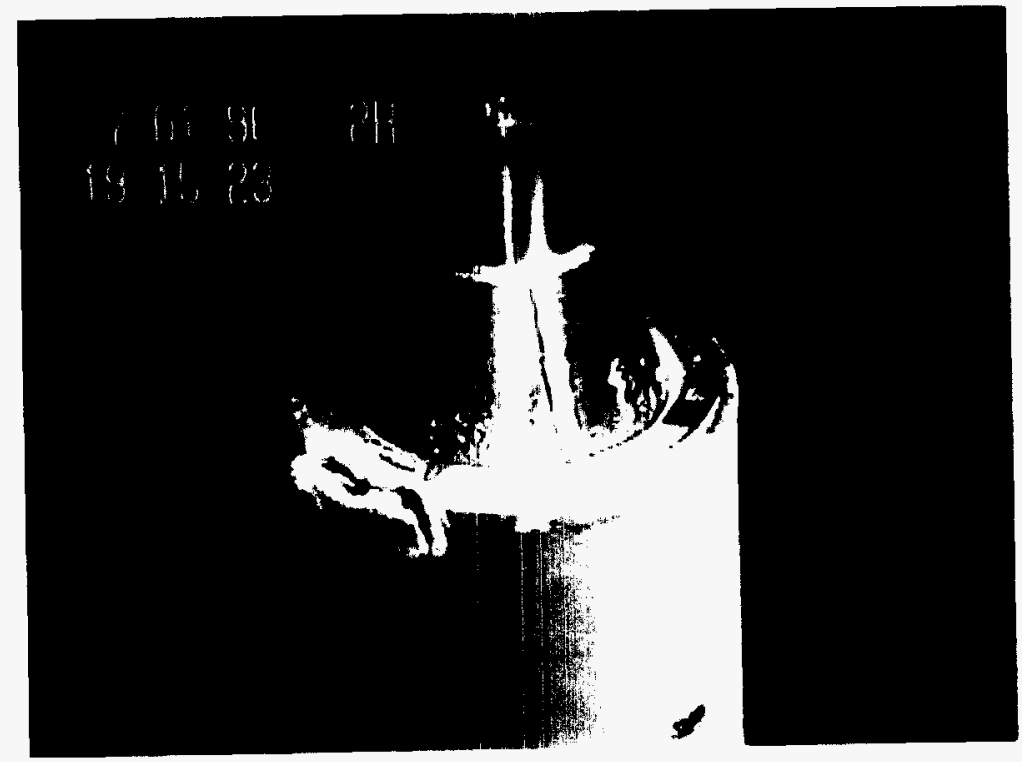




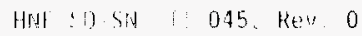

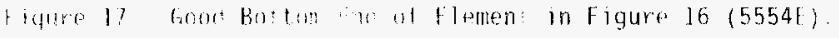

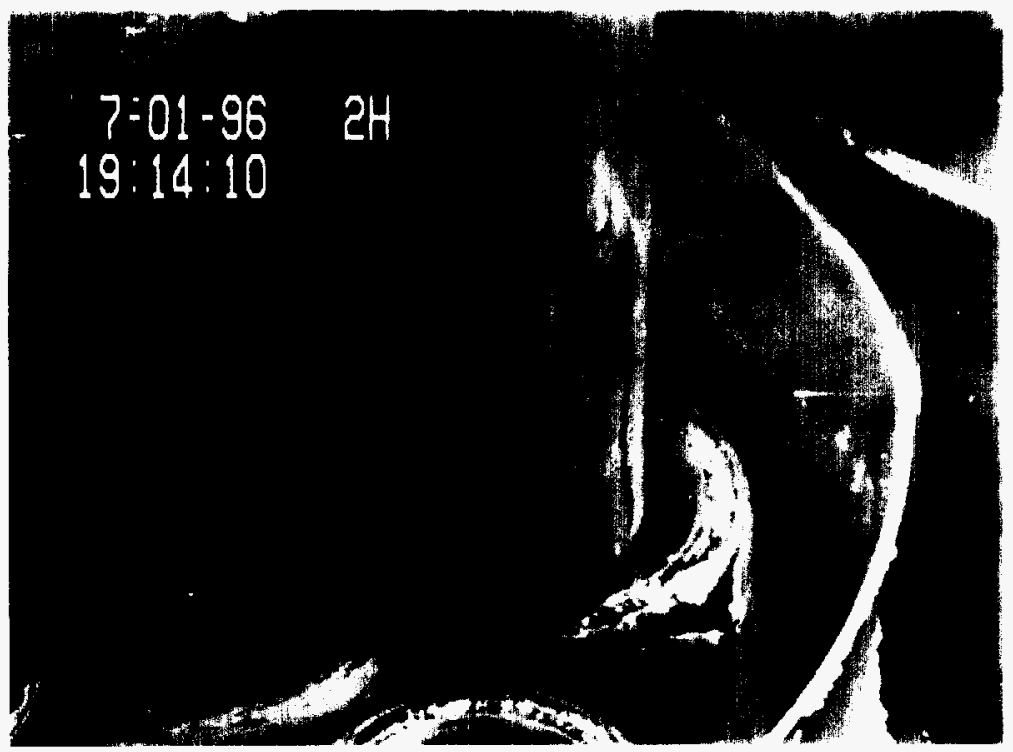

BEST A.TLALI COPY 
Figure 18, Category Changes for the Good Fuel Survey.

INNERS

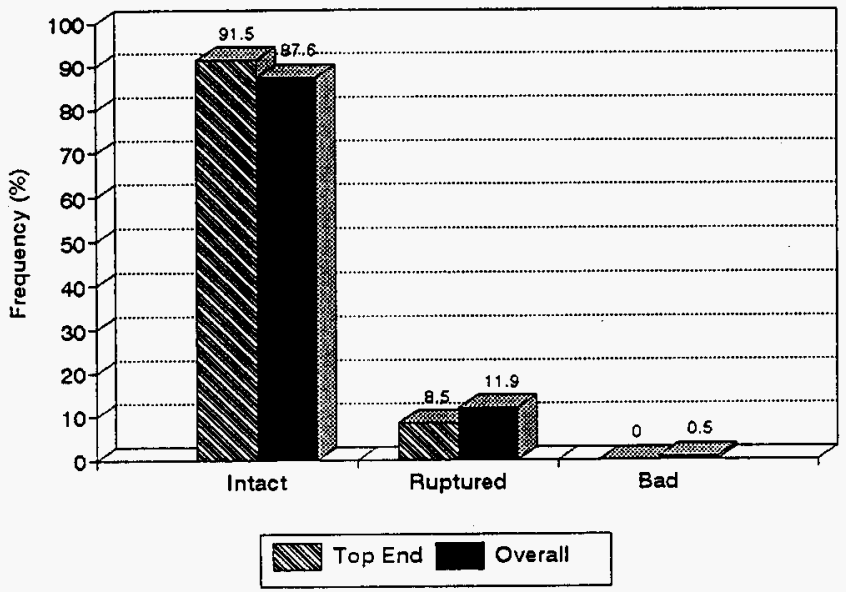

OUTERS

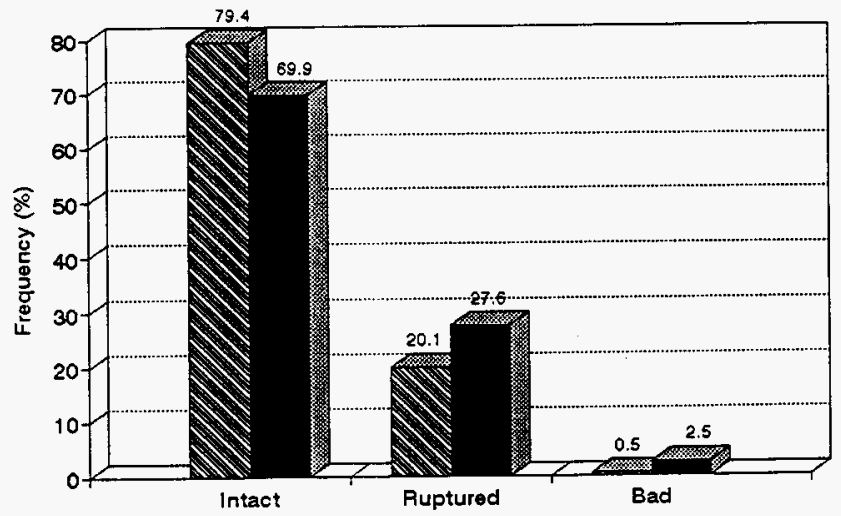

$$
\text { Top End Overall }
$$


HNF-SD-SNF-TI-045, Rev. 0

Figure 19. Category Changes for the Bad Fuel Survey.

INNERS

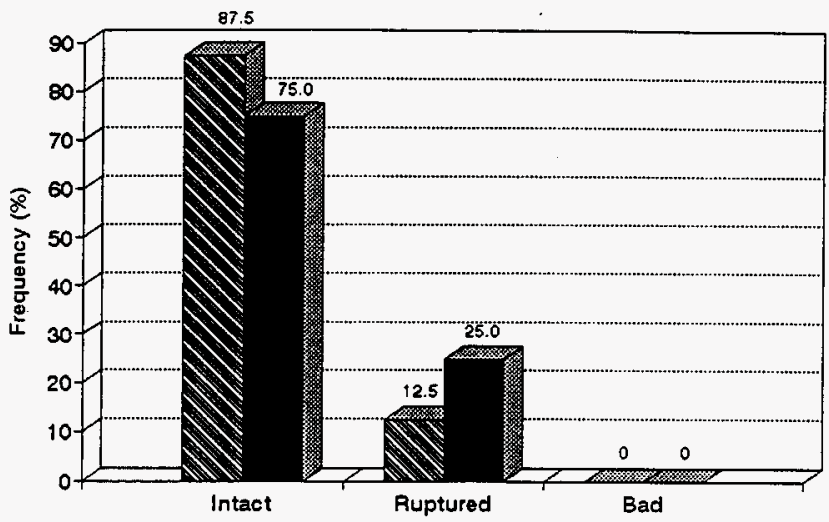

Top End Overall

OUTERS
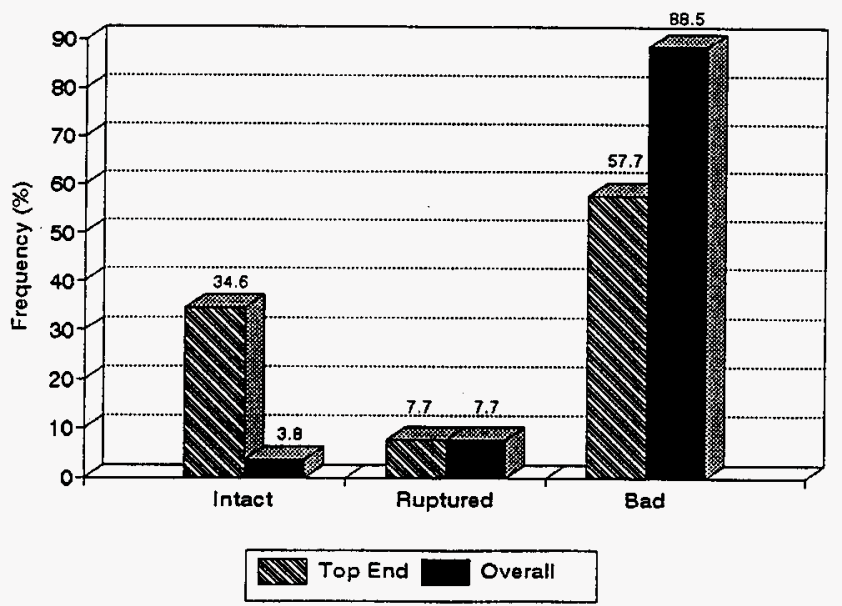


\section{DISTRIBUTION SHEET}

\begin{tabular}{|c|c|c|c|c|c|}
\hline To & \multirow{2}{*}{\multicolumn{3}{|c|}{$\begin{array}{l}\text { From } \\
\text { Spent Nuclear Fuel } \\
\text { Evaluations } / 2 T 650\end{array}$}} & \multicolumn{2}{|l|}{ Page 1 of 2} \\
\hline Distribution & & & & \multicolumn{2}{|c|}{ Date $01 / 30 / 97$} \\
\hline \multirow{2}{*}{\multicolumn{4}{|c|}{$\begin{array}{l}\text { Project Title } \text { Work Order } \\
\text { Spent Nuclear Fue } 1 \text { Project }\end{array}$}} & \multicolumn{2}{|c|}{ EDT No. 617442} \\
\hline & & & & \multicolumn{2}{|l|}{ ECN No. } \\
\hline Name & MSIN & $\begin{array}{l}\text { Text } \\
\text { With All } \\
\text { Attach. }\end{array}$ & Text Only & $\begin{array}{l}\text { Attach./ } \\
\text { Appendix } \\
\text { Only }\end{array}$ & $\begin{array}{l}\text { EDT/ECN } \\
\text { Only }\end{array}$ \\
\hline
\end{tabular}

U.S. Department of Energy.

Richland Operations office

P. G. Loscoe

S7-41 $\quad X$

E. D. Sellers

$57-41$

J. Shuen

G. D. Trenchard

$57-41$

$57-41$

$X$
$X$
$X$
$X$

B \& W Protec, Inc.

T. L. Welsh

T4-40 X

Fluor Daniel Northwest

L. J. Garvin

R3-15

M. Kummerer

D. A. Smith

A3-34

R3-15

$X$
$X$
$X$

ICF Kaiser

G. Baston

R. P. Denise

R3-82

R3-82

$\frac{x}{x}$

Pacific Northwest National Laboratory
J. Abrefah
A. B. Johnson
P7-27
K8-34
P7-27
S. C. Marschman
K9-46
P. A. Scott
R3-87
S. M. Short
$x$
$X$
$X$
$X$
$X$

$x$

SGN Eurisys Services Corp.
R3-86 X
A. L. Pajunen

Duke Engineering \& Services Hanford, Inc.
C. J. Alderman
R. B. Baker
D. W. Bergmann
K. H. Bergsman
A. E. Bridges
W. A. Briggs
L. D. Bruggeman
B. S. Carlisle
S. A. Chastain
R. B. Cowan
C. Defigh Price
D. R. Duncan
J. R. Frederickson

$\begin{array}{ll}R 3-48 & X \\ H 0-40 & X \\ \text { R3-86 } & X \\ \text { R3-48 } & X \\ H 0-40 & X \\ H 0-40 & X \\ H 0-40 & X \\ \text { R3-85 } & X \\ H 0-40 & X \\ \text { R3-86 } & X \\ \text { X3-79 } & X \\ \text { R3-86 } & X \\ \text { R3-86 } & X\end{array}$




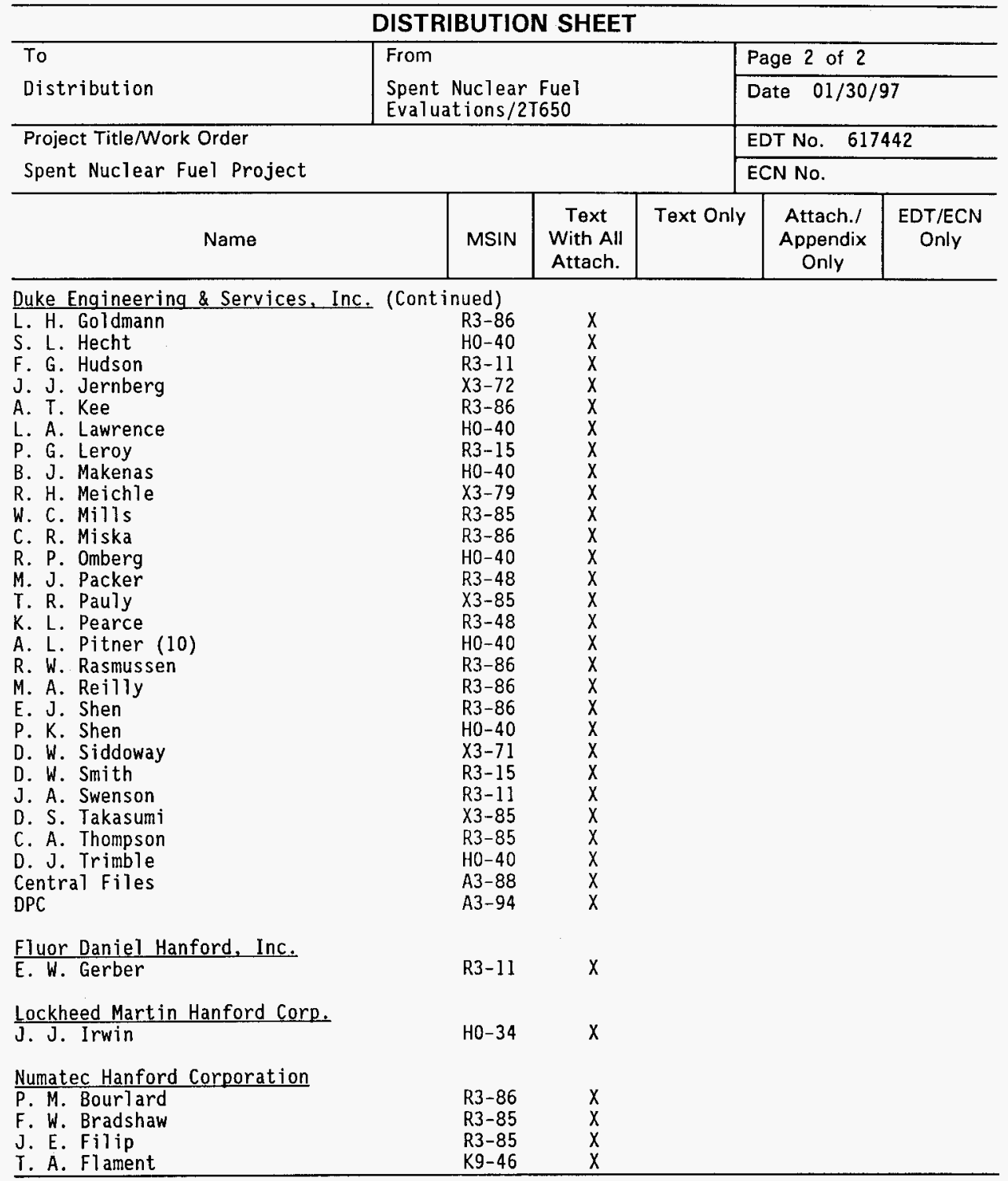

